\title{
Human Rights Due Diligence Policies Applied to Extraterritorial Cooperation to Prevent "Irregular" Migration: European Union and United Kingdom Support to Libya
}

\author{
Carla Ferstman*
}

(Received 24 February 2020; accepted 04 March 2020)

\begin{abstract}
Extraterritorial cooperation —including by providing funds, equipment, training, and technical supporthas become central to policies aimed at preventing access of refugees and "irregular" migrants to particular countries and regions. But cooperating countries and international organizations have due diligence obligations under human rights law to take all reasonable steps to ensure that the cooperation they provide does not result in human rights violations, even when the violations are perpetrated extraterritorially by third parties. Consequently, they can become liable for the failure to exercise due diligence to prevent human rights violations from occurring in the receiving states. Also, they may incur responsibility for the resulting acts where they knowingly aided or assisted the receiving state to commit human rights violations with the support provided.

International organizations and some states have begun to adopt human rights due diligence policies to assess and mitigate the risks of such cooperation. Using the examples of European Union and United Kingdom support to Libya, this Article analyzes the due diligence policies they have applied to extraterritorial cooperation in the area of border control and the detention of refugees and other migrants. It finds that the policies as implemented have provided only superficial scrutiny and argues that they should be made more robust and transparent. Ultimately, this will help mitigate the human rights risks associated with extraterritorial assistance, and ideally help ensure that assistance contributes to the strengthening of human rights protections in recipient countries.
\end{abstract}

Keywords: Due diligence; Libya; Aid; Migrants

\section{A. Introduction}

This Article focuses on extraterritorial support to Libyan authorities involved in border control and the detention of refugees and other migrants, forms of cooperation which have become commonplace. It explains the context in which such support takes place and its potential adverse impact on human rights. This context is used to analyze the due diligence obligation to take all reasonable steps to prevent or avoid a risk of human rights violations occurring, when there is a positive obligation to exercise due diligence and the duty holder knew or ought to have known that

\footnotetext{
${ }^{*}$ Senior Lecturer, University of Essex. I am grateful to Geoff Gilbert, Cathryn Costello, Itamar Mann, and Nora Markard for helpful comments on an earlier draft. This Article was first presented at a workshop on "Accountability for Human Rights Violations in Migration Control” held in Oxford on Nov. 10, 2018, that was funded by an ERC Starter Grant RefMig (Grant Agreement 716968), of which Cathryn Costello is the PI. All errors and omissions remain my own. 
there were insufficient guarantees protecting the parties concerned. ${ }^{1}$ I examine two sets of practices in particular-those of United Kingdom and European Union cooperation and assistance in Libya. The UK is examined as it has a due diligence policy relating to overseas cooperation and assistance, relatively rare among states. The EU is chosen because its involvement in Libya is significant, in that a large portion of member state funding for Libya is channeled through the EU.

Providing support to states that regularly violate human rights can make them more compliant, or it can aid in the further commission of human rights abuses. In the latter case, such support may create potential legal liability of those providing assistance. As Knowles and Watson have argued, the liability risks "should highlight the importance of carefully documenting the decision-making process when it comes to providing assistance so that the rationale is clear." 2

Strengthening human rights protections is an often-cited rationale for providing or increasing extraterritorial support. In this context, human rights due diligence policies are used with increasing frequency to give support to decisions to cooperate. But the policies often have little correlation with due diligence obligations under human rights law. Due diligence policies implemented in the context of extraterritorial cooperation to Libya in areas connected to migration control have tended to lack robustness and transparency. This undermines the legitimacy of the resulting decisions to cooperate. In such circumstances, the due diligence policies can be, and have often become, rubber stamps on potentially questionable decisions to cooperate that serve narrow and oftentimes short-term political interests. Limited risk mitigation also means that the policies do not meet human rights due diligence obligations under human rights law and are less able to engender shifts in program support to better foster rights compliant outcomes.

Due diligence obligations in cooperative scenarios is a relatively underexplored area. There are several analyses that describe cooperative non-entrée policies, including the important work of Gammeltoft-Hansen and Hathaway. ${ }^{3}$ These mainly canvas the operational practice and how it has evolved, ${ }^{4}$ with some also considering the complicity of cooperating states ${ }^{5}$ and international organizations. ${ }^{6}$ There is also growing research on due diligence policies, stemming mainly from developments in the business and human rights field, ${ }^{7}$ as well as the international development

\footnotetext{
${ }^{1}$ See Hirsi Jamaa v. Italy (GC), 2012-II Eur. Ct. H.R. 37, para. 156 (assessing Italy's transfer of migrants to Libya, where the authorities "knew or should have known that there were insufficient guarantees protecting the parties concerned from the risk of being arbitrarily returned to their countries of origin ...."). See also El Masri v. Macedonia, 2012-VI Eur. Ct. H.R. 76.

${ }^{2}$ Emily Knowles \& Abigail Watson, Lawful but Awful? Legal and Political Challenges of Remote Warfare AND WORKING WITH PARTNERs 12 (2018).

${ }^{3}$ See Thomas Gammeltoft-Hansen \& James Hathaway, Non-Refoulement in a World of Cooperative Deterrence, 53(2) Colum. J. Transnat'l L. 235 (2015). See also MaArten Den Heijer, Europe and Extraterritorial Asylum (2012).

${ }^{4}$ See Mariagiulia Giuffré \& Violeta Moreno-Lax, The Rise of Consensual Containment: From Contactless Control to Contactless Responsibility for Migratory Flows, in Research Handbook on InTERnational Refugee Law (Satvinder Singh Juss ed., 2019).

${ }^{5}$ See Anna Liguori, Migration Law and the Externalization of Border Controls: European State Responsibility (2019); Giuseppe Pascale, Is Italy Internationally Responsible for the Gross Human Rights Violations Against Migrants in Libya?, 56 Questions InT'L L. 35 (2019); Vassilis Tzevelekos \& Elena Katselli Proukaki, Migrants at Sea: A Duty of Plural States to Protect (Extraterritorially)?, 86 NordiC J. INT'L L. 427 (2017); Violeta Moreno-Lax \& Martin Lemberg-Pedersen, Border-Induced Displacement: The Ethical and Legal Implications of Distance-Creation through Externalization, 23/24 QUESTIONS INT'L L. 1 (2019).

${ }^{6}$ See Melanie Fink, Frontex Working Arrangements: Legitimacy and Human Rights Concerns Regarding "Technical Relationships," 28(75) Merkourios 20 (2012); Anne Koch, The Politics and Discourse of Migrant Return: The Role of UNHCR and IOM in the Governance of Return, 40(6) J. ETHNIC \& MigRATION STUD. 905 (2014).

${ }^{7}$ See Olivier De Schutter et al., Human Rights Due Diligence: The Role of States (2012); Bürgi Bonanomi, Measuring Human Rights Impacts of Trade Agreements-Ideas for Improving the Methodology: Comparing the European Union's Sustainability Impact Assessment Practice and Methodology with Human Rights Impact Assessment Methodology, 9(3) J. Hum. RTs. Prac. 481, 484-85 (2017).
} 
sector. ${ }^{8}$ Invariably, these policies have not been applied specifically to migration and refugee contexts, nor has there been detailed consideration of whether, and if so, how, due diligence policies satisfy due diligence obligations under human rights law. Research is also lacking on whether they affect and potentially mitigate international responsibility for the ensuing acts in accordance with Article 16 of the International Law Commission's Articles on State Responsibility, which concerns complicity with internationally wrongful acts.

This Article aims to contribute to filling these lacunae. This Article provides an overview of extraterritorial cooperation in the context of border control and the detention of refugees and other migrants, and surveys the human rights challenges faced by refugees and other migrants in Libya. It then proceeds to analyze the nature of human rights due diligence obligations. It considers the different usages of due diligence in the context of extraterritorial cooperation and analyzes how human rights impact and risk mitigation policies can be strengthened to better serve their intended purposes of ensuring that extraterritorial cooperation and assistance do not contribute to human rights violations. It then considers EU and UK cooperation programs in Libya, explaining the due diligence and risk mitigation policies employed by them when deciding whether and how to lend support. This Article also explains the role of parliamentary and other oversight of decisions to cooperate, and outlines the novel resort to litigation in the United Kingdom to enforce due diligence obligations. It also considers the relationship between human rights due diligence obligations and the potential for cooperating states and international organizations to incur international responsibility for their aid or assistance in the commission of an internationally wrongful act.

\section{B. Extraterritorial Cooperation in the Context of Border Control and the Detention of Refugees and Other Migrants}

States, often in cooperation with other states and intergovernmental organizations, have adopted strategies as part of increasingly restrictive migration policies to prevent refugees and migrants from entering their territory, and increasingly to impede them from leaving their own countries of origin or transit. ${ }^{9}$ Such non-entrée policies have had a detrimental impact on individuals' freedom of movement and right to seek asylum, and have exposed them to an array of human rights abuses, including refoulement, slave labor, rape, torture, and killings. ${ }^{10}$

Bilateral cooperation agreements on migration have been used extensively by Australia ${ }^{11}$ and also by the United States ${ }^{12}$ under the guise of regional cooperation for "burden sharing." Cooperation agreements have also been a key ingredient in Europe, along each of the main migration routes into Europe and with transit countries. An important example is Italy, whose 2017

\footnotetext{
${ }^{8}$ See Natalie Bugalski, The Demise of Accountability at the World Bank?, 31(1) Am. U. INT'L L. Rev. 1 (2016); UK Department for International Development (DFID), Due Diligence Guide (2018), https://assets.publishing.service.gov.uk/ government/uploads/system/uploads/attachment_data/file/365186/Due-Diligence-framework.pdf; Australia Department of Foreign Affairs and Trade (DFAT), Due Diligence Framework (Dec. 2017), https://dfat.gov.au/about-us/publications/ Pages/due-diligence-framework.aspx.

${ }^{9}$ See Eur. Parl. Directorate-General for Internal Policies, Enhancing the Common European Asylum System and Alternatives to Dublin: Study for the LIBE Committee 18-24 (2015). See also Gammeltoft-Hansen \& Hathaway, supra note 3, at 244-48; Giuffré \& Moreno-Lax, supra note 4.

${ }^{10}$ See U.N. Human Rights Council, Rep. of the Special Rapporteur on Torture and Other Cruel, Inhuman or Degrading Treatment or Punishment, 36, U.N. Doc. A/HRC/37/50 (Feb. 26, 2018). See also infra Part C.

${ }^{11}$ Sixth Ministerial Conference of the Bali Process on People Smuggling, Trafficking in Persons and Related Transnational Crime, Bali Declaration on People Smuggling, Trafficking in Persons and Related Transnational Crime (Mar. 23, 2016).

${ }^{12}$ See Daniel Ghezelbash, Lessons in Exclusion: Interdiction and Extraterritorial Processing of Asylum Seekers in the United States and Australia, in Exploring the Boundaries of Refugee Law: Current Protection Challenges 90-117 (Jean-Pierre Gauci, et al. eds., 2015); Itamar Mann, Dialectic of Transnationalism: Unauthorized Migration and Human Rights, 1993-2013, 54(2) HARV. INT'L L.J. 315 (2013).
} 
agreement with Libya ${ }^{13}$ - automatically renewed in 2019-has helped Libya take control of search and rescue at sea, and fostered border interdictions and pushbacks. ${ }^{14}$ The cooperation agreement has no provisions to render cooperation and support conditional on the respect of human rights, nor a mechanism to monitor or assess the human rights situation of migrants, issues the UN Committee Against Torture raised with Italy. ${ }^{15}$

Bilateral and multilateral agreements are necessary to implement externalized migration policies and at the same time give a gloss of legality to policies that can result in the breach of individuals' human rights. Cooperation agreements are varied and have focused on: Establishing buffer zones; strengthening border controls; and setting up blanket readmission or admission agreements to receive and process migrants, including by carrying out extraterritorial claims processing and administering "reception" or detention centers. ${ }^{16}$ The forms of cooperation include: Funding; supply of training, equipment, or technical support; ${ }^{17}$ deploying or seconding officials to joint operations or patrols; and oversight of operations in transit countries, in exchange for agreeing to admit and host refugees and migrants.

In order to preserve a veneer of legality, some arrangements-particularly those involving transfers of individuals - have relied on states designating cooperating countries as "safe countries," 18 though such designations have not always been upheld by courts. ${ }^{19}$ Designations have typically relied on political, rather than legal or humanitarian, considerations. Whether a country is actually "safe" will depend on factors such as its willingness and ability to examine asylum claims, respect for the non-refoulement principle, and respect for migrants' human rights. ${ }^{20}$ To bolster the "safety" contention, some cooperation agreements include undertakings that the receiving states will respect the rights of persons transferred to them and will not send them to countries where they face a real risk of persecution (refoulement). This resort to undertakings has been borrowed from the anti-torture ${ }^{21}$ and anti-death penalty ${ }^{22}$ fields. They tend to take the form of non-binding memoranda of understanding and are difficult to monitor and enforce. Once an individual is transferred, the sending state will have little sway with the receiving state, and little vested interest, in advocating for the assurance to be complied with. ${ }^{23}$

\footnotetext{
${ }^{13}$ See Memorandum of Understanding Between Italy and Libya (Feb. 2, 2017) (unofficial trans. available at http:// eumigrationlawblog.eu/wp-content/uploads/2017/10/MEMORANDUM_translation_finalversion.doc.pdf).

${ }^{14}$ See Eur. Parl., Answer to Parliamentary Question Given by Mr. Avramopoulos on Behalf of the European Commission, P-003665/2018 (Sept. 4, 2018).

${ }^{15}$ See U.N. Comm. Against Torture, Concluding Observations on the Fifth and Sixth Combined Periodic Reports of Italy, g 22, U.N. Doc. CAT/C/ITA/CO/5-6 (Dec. 18, 2017).

${ }^{16}$ See Gammeltoft-Hansen \& Hathaway, supra note 3, at 248-57; Evelien Brouwer, Extraterritorial Migration Control and Human Rights: Preserving the Responsibility of the EU and Its Member States, in EXTRATERRITORIAL IMMIGRATION CONTROL: Legal Challenges 199, 211 (Bernhard Ryan \& Valsamis Mitsilegas eds., 2010).

${ }^{17}$ See Eur. Comm., Migration on the Central Mediterranean Route: Managing Flows, Saving Lives, JOIN(2017) 4 final (Jan. 25, 2017).

${ }^{18}$ Steve Peers, The Final EU/Turkey Refugee Deal: A Legal Assessment (Mar. 18, 2016), http://eulawanalysis.blogspot.co.uk/ 2016/03/the-final-euturkey-refugee-deal-legal.html.

${ }^{19}$ See Ilias and Ahmed v. Hungary (GC), App. No. 47287/15, paras. 139-64 (Nov. 21, 2019), http://hudoc.echr.coe.int/eng? $\mathrm{i}=001-198760$.

${ }^{20}$ See Maria-Teresa Gil-Bazo, The Safe Third Country Concept in International Agreements on Refugee Protection: Assessing State Practice, 33 Neth. Q. Hum. RTs. 42 (2015); Michelle Foster, Protection Elsewhere: The Legal Implications of Requiring Refugees to Seek Protection in Another State, 28 Mich. J. INT'L L. 223 (2007).

${ }^{21}$ See Nina Larsaeus, The Use of Diplomatic Assurances in the Prevention of Prohibited Treatment (Refugee Stud. Ctr., Working Paper No. 32, 2006).

${ }^{22}$ See Bibi van Ginkel \& Federico Rojas, Use of Diplomatic Assurances in Terrorism-related Cases: In Search of a Balance Between Security Concerns and Human Rights Obligations, InT'L CTr Counter-Terrorism-The Hague (2011), https://www. icct.nl/download/file/ICCT-van-Ginkel-EM-Paper-Diplomatic-Assurances.pdf.

${ }^{23}$ See, e.g., Comm. Against Torture, Agiza v. Sweden, U.N. Doc. CAT/C/34/D/233/2003, Decision, para. 13.4 (May 24, 2005); Eshonkulov v. Russia, App. No. 68900/13, para. 39 (Jan. 15, 2015), http://hudoc.echr.coe.int/eng?i=001-150713.
} 
Despite the "safe" contention, affected individuals have been subjected to a raft of human rights abuses in some receiving states, including: Denial of procedural rights; denial of the right to seek asylum; arbitrary detention; torture and other cruel, inhuman, or degrading treatment; sexual and other forms of gender-based violence; slavery and slave-like practices; onward refoulement; ${ }^{24}$ enforced disappearances; killings; and denial of basic requirements for life such as food, medicine, and shelter. ${ }^{25}$ In some cases, individuals have been left to the prey of corrupt officials or gangs who have used extortion and threats of further violence in exchange for promises of safety. ${ }^{26}$

\section{The Human Rights Context for Migrants in Libya}

Libya has for a long time been a destination for migrants seeking employment, as well as a transit country for onward travel to the EU. According to UNHCR, "as of June 2018, over 679,000 migrants from over 40 nationalities were recorded to be living in Libya, although the actual number is estimated to be up to one million." ${ }^{27}$ Since 2011, Libya has been largely controlled by armed militia groups loosely connected to government factions. The power vacuum and instability has allowed elements within these militia groups and others, sometimes with the collusion of government officials, ${ }^{28}$ to exploit migrants' vulnerability — many of whom have been subjected to extortion, slave labor, rape, torture, killings, trafficking, and smuggling. The abuses are fueled by discriminatory treatment, especially of those from sub-Saharan Africa and belonging to religious minorities. ${ }^{29}$ The situation has been called a "human rights crisis." 30

Libya is not party to the Refugee Convention and has no domestic law for considering asylum claims. Detention of irregular migrants including refugees ${ }^{31}$ is standard and indefinite, given the criminalization of undocumented entry into the country. Immigration detention is poorly regulated, with no procedures in place to regulate detention and release. In that context, UNHCR and the International Organization for Migration (IOM) have established programs to release "vulnerable people" on humanitarian grounds, ${ }^{32}$ return some people to their countries of origin, ${ }^{33}$ or send them to third countries like Niger and Rwanda, in principle for onward resettlement. $^{34}$

The Libyan authorities detain migrants, whether apprehended on land or intercepted at sea by the Libyan Coast Guard. According to UNHCR: "During rescues/interception operations at sea, the LCG [Libyan Coast Guard] have reportedly been involved in human rights violations against

\footnotetext{
${ }^{24}$ See Hirsi Jamaa, 2012-II Eur. Ct. H.R. at para. 156.

${ }^{25}$ See Giuffré \& Moreno-Lax, supra note 4.

${ }^{26}$ See Judith Sundersland \& Hanan Saleh, No Escape from Hell: EU Policies Contribute to Abuse of Migrants in Libya, Human Rights WATch 14 (2019), https://www.hrw.org/report/2019/01/21/no-escape-hell/eu-policies-contribute-abusemigrants-libya\#page.

${ }^{27}$ U.N. High Comm'r for Refugees (UNHCR), UNHCR Position on Returns to Libya-Update II, para. 16 (Sept. 2018).

${ }^{28}$ See Sundersland \& Saleh, supra note 26, at 14.

${ }^{29} \mathrm{See}$ U.N. Comm. on the Prot. of the Rights of All Migrant Workers and Members of Their Families, Concluding Observations on the Initial Report of Libya, 28, U.N. Doc. CMW/C/LBY/CO/1 (May 8, 2019).

${ }^{30}$ See Office of the U.N. High Comm'r for Human Rights (OHCHR) \& United Nations Support Mission in Libya (UNSMIL), Detained and Dehumanised: Report on Human Rights Abuses Against Migrants in Libya 1 (Dec. 13, 2016), http://www.ohchr.org/Documents/Countries/LY/DetainedAndDehumanised_en.pdf.

${ }^{31}$ See UNHCR, supra note 27 , at paras. $15,19$.

${ }^{32}$ See UNHCR, supra note 27 , at para. 23.

${ }^{33} \mathrm{See}$ Press Release, IOM, IOM Voluntary Humanitarian Returns Continue in Libya as Number of Detained Migrants Soars (Aug. 10, 2018).

${ }^{34}$ See Leonie Jegen \& Franzisca Zanker, Spirited Away: The Fading Importance of Resettlement in the Emergency Transit Mechanism in Rwanda, Eur. CTR. FOR Dev. Pol. MGMT. (2019); UNHCR, Third Group of Refugees Evacuated to Rwanda from Libya with UNHCR Support (Nov. 25, 2019), http://www.unhcr.org/en-us/news/press/2019/11/5ddbd69b4/third-grouprefugees-evacuated-rwanda-libya-unhcr-support.html.
} 
refugees, asylum-seekers and migrants, including the deliberate sinking of boats using firearms. The LCG have also been accused of colluding with smuggling networks." ${ }^{35}$ In May 2019, the UN Committee on Migrant Workers expressed concern at the large number of reports of collusion and complicity of state officials with smuggling and trafficking networks, and extortion of the families of detained migrant workers. ${ }^{36}$

Abuses and inhumane conditions such as overcrowding, poor sanitation, limited food, water, and medical supplies, and insecurity are rife in migrant detention centers. ${ }^{37}$ Also, there have been reports of detention centers housing migrants being attacked with migrants shot. ${ }^{38}$ Several NGOs and UN agencies provide services in detention centers, though they are hampered by poor security. Furthermore, these interventions have been accused by some of serving "to prop up a system of abusive, arbitrary detention and provide a fig leaf for EU migration control policies." 39

As a result of the dire human rights situation, UN agencies and monitoring bodies have regularly called on states to end transfers and returns to Libya. ${ }^{40}$ The International Organization for Migration program to return persons to their countries of origin and UNHCR programs to send persons to third countries like Niger and Rwanda are clear responses to the desperate situation for migrants in Libya. Nevertheless, considering those circumstances, it is difficult to contend that such returns or transfers are voluntary.

\section{Due Diligence}

As explained in the section above, migrants in Libya face a real risk of severe human rights violations. It is therefore crucial that states and international organizations do not directly or indirectly, through their cooperation, fuel those human rights violations. The obligation to exercise due diligence to prevent human rights violations perpetrated by others is a useful lens through which to assess the appropriateness of extraterritorial cooperation.

\section{The Meaning and Content of Due Diligence}

In very general terms, due diligence refers to a standard of conduct required to avoid a likely or foreseeable undesirable outcome. It is a principle of fault in many domestic legal systems, and has been incorporated into a number of international treaties to delineate the conduct needed to discharge legal obligations. ${ }^{41}$ Typically, it creates an obligation on the duty holder to protect others against unlawful interferences by third parties and, if such interferences have occurred, to punish the persons responsible - a positive obligation to take action. This is distinct from any duties that may be held by the duty holder in relation to its own conduct, which may additionally

\footnotetext{
${ }^{35}$ UNHCR, supra note 27, at para. 22. See also Panel of Experts on Libya, Letter dated June 1, 2017 from the Panel of Experts on Libya addressed to the President of the Security Council, gg 104-05, U.N. Doc. S/2017/466 (June 1, 2017).

${ }^{36}$ See U.N. Comm. on the Prot. of the Rights of All Migrant Workers and Members of Their Families, Concluding Observations on the Initial Report of Libya, 26, U.N. Doc. CMW/C/LBY/CO/1 (May 8, 2019).

${ }^{37}$ See UNHCR, supra note 27, at para. 19; OHCHR \& UNSMIL, supra note 30, at 14-19.

${ }^{38}$ See Amnesty Int'l, Libya: Horrific Attack Targeting Refugees and Migrants at Detention Centre Must be Investigated as a War Crime (Apr. 24, 2019, 5:04 PM), https:/www.amnesty.org/en/latest/news/2019/04/libya-horrific-attack-targetingrefugees-and-migrants-at-detention-centre-must-be-investigated-as-a-war-crime/; Sally Hayden, Libya Migrants Recount Horrors of Tajoura Detention Centre Attack, AL JAZEERA (July 4, 2019), http://www.aljazeera.com/news/2019/07/libyamigrants-recount-horrors-tajoura-detention-centre-attack-190704053421671.html.

${ }^{39}$ Sundersland \& Saleh, supra note 26 , at 28.

${ }^{40} \mathrm{UNHCR}$, supra note 27 , at para. 37. See also id. at paras. $39,41,42$.

${ }^{41}$ See generally Jan Arno Hessbruegge, The Historical Development of the Doctrines of Attribution and Due Diligence in International Law, 36 N.Y.U. J. INT'L L. \& Pol. 265 (2004); Duncan French \& Tim Stephens, ILA Study Group on Due Diligence in International Law: First Report, INT'L LAW Assoc. (Mar. 7, 2014).
} 
involve an obligation of result. ${ }^{42}$ Early international jurisprudence concerning due diligence focused on the state obligation to prevent wrongful acts by its citizens against foreigners outside its jurisdiction, ${ }^{43}$ suggesting early on that due diligence obligations can also extend to extraterritorial scenarios.

\section{Sources of Due Diligence Obligations}

When a state or other duty holder has an obligation to exercise due diligence, it requires them to take reasonable precaution to avert the risks of the bad outcome materializing. What will be deemed to be reasonable steps will depend on how the particular due diligence obligation is framed, the specific context underpinning the risks, and the capacities and opportunities for action of the duty holders. In the Corfu Channel case, for example, the International Court of Justice held that in accordance with the due diligence obligation, Albanian authorities were obligated to notify the existence of a minefield and to warn those at risk of imminent danger. ${ }^{44}$ Due diligence has also become an important principle of environmental law. States must use all means at their disposal to avoid activities under their jurisdiction from causing significant damage to the environment of another state. ${ }^{45}$ The International Law Commission's Draft Articles on the Prevention of Transboundary Harm from Hazardous Activities incorporate an obligation on states to "take all appropriate measures to prevent significant transboundary harm or at any event to minimize the risk thereof," and make specific reference to the importance of environmental impact assessments. ${ }^{46}$ The Commentaries clarify that " $\left.\mathrm{t}\right]$ he standard of due diligence against which the conduct of the State of origin of [transboundary environmental harm] should be examined is that which is generally considered to be appropriate and proportional to the risk of transboundary harm in the particular instance." 47

Under human rights law, due diligence has most often been applied to states' efforts to prevent, stop, and respond to abuses by non-state actors ${ }^{48}$ — whether private individuals, armed opposition groups, or corporate entities. It includes not only the obligation to prevent, but also to punish, investigate, or redress the harm caused. ${ }^{49}$ For example, under Article 3 of the European Convention on Human Rights, in addition to the negative state obligations to refrain from inflicting harm that would constitute torture or other forms of cruel or inhuman treatment, a state also has positive due diligence obligations to prevent such harm caused by private actors, and to investigate and punish it where it was not effectively prevented. ${ }^{50}$ Similar positive obligations have been identified for the right to life. ${ }^{51}$ In Opuz v. Turkey, the European Court of Human Rights

\footnotetext{
${ }^{42}$ Bonnitcha \& McCorquodale make this distinction when explaining the different types of obligations in the business and human rights framework. See Jonathan Bonnitcha \& Robert McCorquodale, The Concept of "Due Diligence" in the UN Guiding Principles on Business and Human Rights, 28(3) EUR. J. INT'L L. 899 (2017).

${ }^{43}$ See S.S. Lotus (France v. Turkey), Judgment, 1927 P.C.I.J. (ser. A) No. 10 (Sept. 7).

${ }^{44}$ See Corfu Channel (U.K. v. Alb.), Judgment, 1949 I.C.J. 4 (Apr. 9).

${ }^{45}$ See Pulp Mills on the River Uruguay (Arg. v. Urug.), Judgment, 2010 I.C.J. 14, g 101 (Apr. 20).

${ }^{46}$ See id. at 99 204-19. See also Report of the International Law Commission on the Work of its Fifty-Third Session (23 April - 1 June and 2 July - 10 August 2001), 56 U.N. GAOR Supp. No. 10, at 36, 45, U.N. Doc. A/56/10 (2001), reprinted in [2001] 2 Y.B. Int'l L. Comm. 26 [hereinafter ARS], arts. 3, 7; Econ. Comm'n for Eur., Application of Environmental Impact Assessment Principles to Policies, Plans and Programmes, U.N. Doc. ECE/ENVWA/27 (Jan. 1992).

${ }^{47} \mathrm{ARS}$, id. at 154 .

${ }^{48}$ See Andrew Clapham, Human Rights Obligations of Non-state Actors 349-419 (2006). See also Yakin Ertürk (Special Rapporteur on Violence Against Women, its Causes and Consequences), The Due Diligence Standard as a Tool for the Elimination of Violence Against Women, 35, U.N. Doc. E/CN.4/2006/61 (Jan. 20, 2006); Convention on Preventing and Combatting Violence Against Women art. 5, opened for signature May 11, 2011, C.E.T.S. No. 210 (entered into force Aug. 1, 2014).

${ }^{49}$ See U.N. Human Rights Comm., General Comment No. 31: The Nature of the General Legal Obligation Imposed on States Parties to the Covenant, 8, U.N. Doc. CCPR/C/21/Rev.1/Add. 13 (May 26, 2004).

${ }^{50}$ See Z v. United Kingdom (GC), 2001-V Eur. Ct. H.R., para. 73. See also U.N. Comm. Against Torture, General Comment No. 2: Implementation of Article 2 by States Parties, 18, U.N. Doc. CAT/C/GC/2 (Jan. 24, 2008).

${ }^{51}$ See U.N. Human Rights Comm., General Comment No. 36: Article 6: Right to Life, g 7, U.N. Doc. CCPR/C/GC/36 (Sept. 3, 2019).
} 
recognized that Turkey was obligated to exercise due diligence to prevent the killing of the applicant's mother. ${ }^{52}$ Turkey failed to do so when it discontinued criminal proceedings against the applicant's spouse, and failed to detain him or to implement protective measures or take other appropriate action in respect of the violent threats made by him. ${ }^{53}$ This duty to protect is only an obligation of means. Due diligence obligations have also been incorporated into human rights assessment methodologies for the right to health ${ }^{54}$ and the right to food. ${ }^{55}$

An early precursor to the approximation of human rights and international criminal law, the Genocide Convention sets out a duty to undertake to prevent and punish genocide. ${ }^{56}$ In the Bosnia Genocide case, the International Court of Justice clarifies that a failure to exercise due diligence occurs "if the State manifestly failed to take all measures to prevent genocide which were within its power, and which might have contributed to preventing the genocide." 57 The state must have had "the capacity to influence effectively the action of persons likely to commit, or already committing, genocide." 58 Serbia's international responsibility was engaged for failing to exercise due diligence in taking all means reasonably available to prevent the harm from occurring. ${ }^{59}$

\section{Due Diligence Obligations in Relation to Extraterritorial Scenarios}

The obligation to exercise due diligence will normally be engaged when a state's-or organization's - overall jurisdiction to protect and fulfill human rights is engaged-usually, this is in relation to conduct taking place within its territory or subject to its jurisdiction, which also includes extraterritorial exercise of jurisdiction. ${ }^{60}$ But there are additional circumstances when due diligence obligations may be engaged, which may depend on the relationship between the dutybearer and the wrongdoer. ${ }^{61}$ Arguably, the closer the relationship and the capacity to influence, the clearer is the obligation of diligence. Engagement in or support of wrongful conduct can give rise to a heightened form of diligence, what Hakimi refers to as a "special duty to protect which is different to and above that of other actors." 62 Similarly, Stephens and French, referring to the Bosnia Genocide case, have argued that "in some circumstances a State may be under a specific obligation to use best efforts to gain knowledge of activity within its territory or jurisdiction." 63 This is key to extraterritorial non-entrée policies, which thrive on willful blindness.

\footnotetext{
${ }^{52}$ See Opuz v. Turkey, 2009-I Eur. Ct. H.R. 107, paras. 137-49.

${ }^{53}$ See id.

${ }^{54}$ See U.N. Comm. on Econ., Soc. and Cultural Rights, General Comment No. 14: The Right to the Highest Attainable Standard of Health (Article 12 of the International Covenant on Economic, Social and Cultural Rights) g 51, U.N. Doc. E/C.12/2000/4 (Aug. 11, 2000). See also Paul Hunt \& Gillian MacNaughton, Impact Assessments, Poverty and Human Rights: A Case Study using the Right to the Highest Attainable Standard of Health (UNESCO, Health and Human Rights, Working Paper Series No. 6, 2006).

${ }^{55}$ See Olivier De Schutter (Special Rapporteur on the Right to Food), Guiding Principles on Human Rights Impact Assessments of Trade and Investment Agreements, U.N. Doc. A/HRC/19/59/Add.5 (Dec. 19, 2011).

${ }^{56}$ See Convention on the Prevention and Punishment of the Crime of Genocide art. 1, opened for signature Dec. 9, 1948,78 U.N.T.S. 277 (entered into force Jan. 12, 1951).

${ }^{57}$ Application of the Convention on the Prevention and Punishment of the Crime of Genocide (B.H. v. S.M.), Judgment, 2007 I.C.J. 43, 430 (Feb. 26) [hereinafter Bosnia Genocide Case].

${ }^{58} \mathrm{Id}$.

${ }^{59}$ See id. $971(5)$.

${ }^{60}$ See International Covenant on Civil and Political Rights art. 2(1), opened for signature Dec. 16, 1966, 999 U.N.T.S. 171 (entered into force Mar. 23, 1976) [hereinafter ICCPR].

${ }^{61}$ See, e.g., Ilaşcu v. Moldova \& Russia (GC), 2004-VII Eur. Ct. H.R., para. 331 (stating "even in the absence of effective control over the Transdniestrian region, Moldova still has a positive obligation under Article 1 of the Convention to take the diplomatic, economic, judicial or other measures that it is in its power to take and are in accordance with international law to secure to the applicants the rights guaranteed by the Convention").

${ }^{62}$ Monica Hakimi, State Bystander Responsibility, 21 EUR. J. INT'L L. 341, 367 (2010).

${ }^{63}$ Duncan French \& Tim Stephens, ILA Study Group on Due Diligence in International Law: First Report 12, INT'L LAW Assoc. (July 2016).
} 
Human rights due diligence obligations relating to extraterritorial scenarios have been affirmed in relation to unilateral coercive measures. ${ }^{64}$ Also, the UN's human rights due diligence policy related to UN support for non-UN security forces ${ }^{65}$ regulates the circumstances in which peacekeeping and other UN forces may cooperate with government or other security forces in situ. The policy requires an assessment of whether there are substantial grounds for believing that there is a real risk that the intended recipient of support will commit grave violations of international humanitarian, human rights, or refugee law. It applies to violations that may be committed by the recipients of UN support in the context or the period of support. The due diligence assessment must take place before support is provided, and among the factors to be considered are the human rights record of the potential recipients, the record of holding past violators accountable, prevention mechanisms in place, the legislative and policy framework applicable to potential recipients, and the feasibility of putting in place an effective monitoring framework. Also, relevant considerations are the UN's capacity to influence and the risks of not providing support. If the risk is evaluated as high or very high, ${ }^{66}$ it may be concluded that support should not be provided unless the UN entity considers that it can reduce the risk to a satisfactory level through various mitigation measures.

Both UN and regional human rights bodies have identified extraterritorial due diligence obligations in relation to third-party actions that extend further than a state's own jurisdictional control. The UN Human Rights Committee determined that states' due diligence obligations relating to the right to life extend to "activities having a direct and reasonably foreseeable impact on the right to life of individuals outside their territory, including activities taken by corporate entities based in their territory or subject to their jurisdiction." ${ }^{7}$ Similarly, the Committee on Economic, Social and Cultural Rights gives the example of a state that has influence outside its territory, who can control the activities of corporations domiciled in its territory but operating abroad. ${ }^{68}$ It determined that state responsibility can be engaged "even if other causes have also contributed to the occurrence of the violation, and even if the state had not foreseen that a violation would occur, provided such a violation was reasonably foreseeable." ${ }^{69}$ Thus, even outside a context of effective control over an area, in the sense of jurisdiction, there may be instances in which a state may nevertheless have influence over a particular entity, because of the extraterritorial reach of regulatory frameworks. There is no reason why this would not apply to state institutions carrying out development or other assistance work overseas- the sending

\footnotetext{
${ }^{64}$ See Human Rights Council, Research-Based Progress Report of the Human Rights Council Advisory Committee Containing Recommendations on Mechanisms to Assess the Negative Impact of Unilateral Coercive Measures on the Enjoyment of Human Rights and to Promote Accountability, gg 43-58, U.N. Doc. A/HRC/28/74 (Feb. 10, 2015).

${ }^{65}$ See U.N. Secretary-General, Identical Letters dated Feb. 25, 2013 from the Secretary-General addressed to the President of the General Assembly and to the President of the Security Council, U.N. Doc. A/67/775-S/2013/110 (Mar. 5, 2013).

${ }^{66}$ The Guidance Note on the policy explains that:
}

A high level risk means that, on the same basis, there is a real likelihood that grave violations will be committed by the intended recipients and will remain unaddressed and that the UN entity will therefore be obliged to withhold or suspend support under the HRDDP. This will cause the UN entity to question whether it wants to engage with the intended recipient at all or exclude some recipients (individuals, units, etc.) from the intended support or decide to reassess the type of support needed by the security forces concerned.

See United Nations, Guidance Note - Human Rights Due Diligence Policy on UN Support to Non-United Nations SECURITY FORCES 23-24 (2015). There is no explanation of what would constitute a "very high" risk.

${ }^{67}$ U.N. Human Rights Comm., General Comment No. 36: Article 6 of the International Covenant on Civil and Political Rights, on the Right to Life, 22, U.N. Doc. CCPR/C/GC/36 (Oct. 30, 2018). See also U.N. Human Rights Committee, supra note 49 , at 8 .

${ }^{68}$ See U.N. Comm. on Econ., Soc. and Cultural Rights, General Comment No. 24: State Obligations Under the International Covenant on Economic, Social and Cultural Rights in the Context of Business Activities, 28, U.N. Doc. E/C.12/GC/24 (Aug. 10, 2018)

${ }^{69} \mathrm{Id}$. at 32. 
government would retain control over its institutions regardless of where they operate. Nevertheless, this position is controversial, particularly in respect of the jurisdictional reach of the European Convention on Human Rights to secure for everyone within their jurisdiction the rights and freedoms defined in the Convention, which has been strictly interpreted. ${ }^{70}$

If the duty holder fails to exercise due diligence, it may be liable for this failing. As the Inter-American Court of Human Rights made clear:

An illegal act which violates human rights and which is initially not directly imputable to a State ... can lead to international responsibility of the State, not because of the act itself, but because of the lack of due diligence to prevent the violation or to respond to it as required by the Convention. ${ }^{71}$

If the duty holder exercises due diligence but the undesirable outcome materializes nevertheless, it will not have breached its due diligence obligations. Whether it may be liable for complicity in the commission of an eventual breach is a separate matter; though invariably, the appropriate exercise of due diligence will serve to undermine any claim of aiding and assisting in the commission of an internationally wrongful act. ${ }^{72}$

The due diligence principle has also been used as a management tool or fact-finding process not only by governments, but also by companies, ${ }^{73}$ international organizations, ${ }^{74}$ and nongovernmental organizations ${ }^{75}$ to gain knowledge, assess, manage, and mitigate a variety of legal and operational risks, and help determine whether certain actions should be pursued or discontinued. There is no one standard approach to the assessment of risk, and there is considerable variation in the complexity and quality of both assessment methodologies and the resulting assessments.

The Guiding Principles on Business and Human Rights underscore the importance of human rights due diligence for agencies linked formally or informally to the state-such as development agencies - that provide support and services, where the nature of business operations or operating contexts pose significant risk to human rights. ${ }^{76}$

\footnotetext{
${ }^{70}$ The ECtHR has so far avoided the concept of complicity. See Al Nashiri v. Poland, App. No. 28761/11, paras. 485,509 (July 24, 2014), http://hudoc.echr.coe.int/eng?i=001-146044.

${ }^{71}$ Velásquez Rodríguez v. Honduras, Merits, Reparations, and Costs, Judgment, Inter-Am. Ct. H.R. (ser. C) No. 4, 172 (July 29, 1988). See also Environment and Human Rights, Advisory Opinion OC-23/18, Inter-Am. Ct. H.R. (ser. A) No. 23 (Nov. 15, 2017) (recognizing that states are obligated to adopt all necessary measures to avoid that activities carried out on their territory or under their control affect the rights of individuals within or outside their territory).

${ }^{72}$ See supra Section D.II.

${ }^{73}$ See U.N. Office of the High Comm'r for Human Rights, Guiding Principles on Business and Human Rights, U.N. Doc. HR/PUB/11/04 (June 16, 2011); Yadaira Orsini \& Roper Cleland, Human Rights Due Diligence in Conflict Affected Settings: Guidance for Extractives Industries, InT'L Alert (Mar. 2018); OECD, Due DiligenCE GuidAnCE FOR Responsible Business Conduct (2018); Gabriela Contreras, et al., Self-Regulation in Sustainable Finance: The Adoption of the Equator Principles, 122 WORLD DEV. 306 (2019).

${ }^{74}$ See, e.g., U.N. Secretary-General, supra note 65; Giedre Jokubauskaite, The World Bank Environmental and Social Framework in a Wider Realm of Public International Law, 32(3) LEIDEN J. INT'L L. 457 (2019); INTERNATIONAL FINANCE Corporation (IFC), Environmental and Social Review Procedures (ESRP) Manual (2016), www.ifc.org/esrp; United Nations Development Programme (UNDP), Human Development Impact Assessment of Trade Policy: A Toolkit, Inclusive Growth and Poverty Reduction, UNDP Asia-PACIFIC RegIONAL CENTRE (Sept. 2012); Democratic Republic of the Congo Sanctions Committee, Due Diligence Guidelines for the Responsible Supply Chain of Minerals from Red Flag Locations to Mitigate the Risk of Providing Direct or Indirect Support for Conflict in the Eastern Part of the Democratic Republic of the Congo, U.N. SECURITY COUNCIL, https://www.un.org/securitycouncil/sites/www.un.org.securitycouncil/files/ due_diligence_guidelines.pdf.

${ }^{75}$ See An Analysis of Contemporary Anti-Diversion Policies and Practices of Humanitarian Organizations, HARV. L. SCH. (May 2014), http://blogs.harvard.edu/cheproject/files/2013/10/CHE_Project_-_Anti-Diversion_Policies_of_Humanitarian_ Organizations_May_2014.pdf.

${ }^{76}$ See U.N. Office of the High Comm'r for Human Rights, supra note 73, at 6 (discussing principle 4). See Daria Davitti, Beyond the Governance Gap: Accountability in Privatized Migration Control, in this issue.
} 
The Guiding Principles explain that businesses should have in place due diligence processes to identify, prevent, mitigate, and account for how they address human rights impacts, as well as systems to remediate adverse human rights impacts. ${ }^{77}$ According to these principles, states are obligated to protect against human rights abuse by third parties, including business enterprises, ${ }^{78}$ and thus states have a clear interest in ensuring that businesses put in place adequate due diligence processes. Due diligence is also an important feature of risk frameworks involving international development and development financing. ${ }^{79}$ Assessments must be appropriate to the context and level of risk, carried out prior to the implementation of the activity, and repeated at relevant intervals throughout implementation. There is a need to consider the potential scope, scale, and severity of the impact of a policy or practice in deciding what degree of evidence gathering and consultation is appropriate in any given assessment.

Key aspects that can be distilled from the standards for due diligence assessments are set out below. Given their practical, procedural focus, the distillation stems from the growing array of good practice guidance documents and standards for impact assessments and risk mitigation. Nevertheless, their essence aligns with how human rights law generally understands due diligence obligations, particularly regarding the need to take full cognizance of the risks, the need for transparency, to consult stakeholders, to adequately address the risks, and to put in place adequate remediation.

i) Screening to determine whether an impact assessment is required and scoping, planning, and prioritization to develop the focus for assessment. This should be based on transparent and accessible criteria relating to the severity of risk, determined in advance, or else the process risks becoming ad hoc and subject to outside influence. ${ }^{80}$

ii) The public likely to be affected by the potential harms should be informed and consulted. Consultation processes should provide ample opportunity to respond and for those responses to be considered in the modification of policy. Consideration should be given to the range of stakeholders who should be consulted and the best ways to engage with them. ${ }^{81}$

iii) Assessing actual and potential impacts and integrating and acting upon findings. For human rights assessments, there must be consideration of what aspects are red lines, and what aspects are tradable or manageable from a risk mitigation perspective. Consideration must include a decision not to cooperate, ending cooperation, revising the terms of cooperation. ${ }^{82}$

iv) Monitoring the implementation of the activity as long as it continues and so long as monitoring is required. ${ }^{83}$

\footnotetext{
${ }^{77}$ See U.N. Office of the High Comm'r for Human Rights, supra note 73, at 15 (discussing Principle 15).

${ }^{78}$ See U.N. Office of the High Comm'r for Human Rights, supra note 73, at 3 (discussing Principle 1).

${ }^{79}$ See World Bank, Human Rights Impact Assessments: A Review of the Literature, Differences With other Forms of Assessments AND RELEVANCE FOR DEVElopment (Feb. 2013). See also Jokubauskaite, supra note 74; IFC, supra note 74; UNDP, supra note 74.

${ }^{80}$ See U.N. Office of the High Comm'r for Human Rights, supra note 73, at 8-9, 16 (discussing Principles 7(a), 7(b), 16(d)); De Schutter, supra note 55, $9 g$ 1, 3, 4.4, 7.1, 7.2; Eur. Comm., Operational Guidance on Taking Account of Fundamental Rights in Commission Impact Assessments 10-11 (Commission Staff Working Paper SEC(2011) 567 final, May 6, 2011); OECD, supra note $73, \mathbf{g} 2.1$

${ }^{81}$ See U.N. Office of the High Comm'r for Human Rights, supra note 73, at 19, 22 (discussing Principles 18(b), 20(b)); De Schutter, supra note 55, 99 4.5, 5(c); Orsini \& Cleland, supra note 73, at 23-28.

${ }^{82}$ See De Schutter, supra note 55, gg 3.2, 7.3; Eur. Comm., supra note 80, at 18-22; Orsini \& Cleland, supra note 73, at 9, 14 (discussing Principles 7(c), 7(d), 13(b)); OECD, supra note 73, gg 3.1, 3.2.

${ }^{83}$ See U.N. Office of the High Comm'r for Human Rights, supra note 73, at 18 (discussing Principle 17(c)); De Schutter, supra note 55, 3.3; Eur. Comm., supra note 80, at 22; OECD, supra note 73, 4.1 .
} 
v) Remediation plans and implementation, including accessible grievance processes. Where negative human rights impacts have ensued, these must be addressed. ${ }^{84}$

vi) The process of assessment should be transparent as should the results. A report with the findings should be published, which would help provide an audit trail. ${ }^{85}$

At times, the rationale for the resort to due diligence procedures may not necessarily stem from a sense of legal obligation. ${ }^{86}$ Nevertheless, if there is a legal obligation to exercise due diligence, the standards of diligence - if they are to avert liability — must necessary align with what is required by the legal obligation. ${ }^{87}$ Implementing due diligence processes will only be capable of discharging legal responsibility when the processes adopted correspond to the requirements of the legal obligation.

\section{The Relationship Between Due Diligence and International Responsibility}

As indicated, responsibility for a failure to exercise due diligence derives from the failure of a duty holder to take reasonable steps to avert or prevent an outcome when there is a specific obligation to take such steps. In such circumstances, the state or other duty holder is responsible for its own failure to act. Whether the duty holders separately bear any responsibility for the resulting outcome will depend on whether it can be shown that the duty holders were complicit in the acts that brought about that outcome. This is a separate legal issue.

Article 16 of the Articles on the Responsibility of States for Internationally Wrongful Acts, provides that

A State which aids or assists another State in the commission of an internationally wrongful act by the latter is internationally responsible for doing so if: (a) that State does so with knowledge of the circumstances of the internationally wrongful act; and (b) the act would be internationally wrongful if committed by that State. ${ }^{88}$

Usually, this form of complicity will depend not on the omission of the duty holder, but on its affirmative or positive action, ${ }^{89}$ in this case, aid or assistance. The aid or assistance would not need to be essential or crucial to the performance of the internationally wrongful act, but it should have contributed significantly to that act. ${ }^{90}$ It requires knowledge of the wrongdoing and a causal link between the aid or assistance provided and the wrongdoing committed.

Complicity by omission is less obvious, as usually states would be "entitled to presume that other States would act lawfully." ${ }^{11}$ But some authors suggest that the circumstances may justify complicity by omission. Jackson, for example, refers to "particularly culpable omissions," such as when a state hosting a foreign head of state fails to screen guests attending the visiting head of

\footnotetext{
${ }^{84}$ See U.N. Office of the High Comm'r for Human Rights, supra note 73, at 14, 16, 24, 28-34 (discussing Principles 13(a), 15(c), 22, 26, 27, 28, 29, 30, 31); Orsini \& Cleland, supra note 73, at 63; OECD, supra note 73, g9 6.1, 6.2.

${ }^{85}$ See U.N. Office of the High Comm'r for Human Rights, supra note 73, at 73 (discussing Principles 21(a), 21(b)); De Schutter, supra note 55 , gg 7.4, 7.5, 7.6.

${ }^{86}$ See Neil McDonald, The Role of Due Diligence in International Law, 68 INT'L \& CoMP. L.Q. 1041, 1049-50 (2019). See also Bonnitcha \& McCorquodale, supra note 42.

${ }^{87}$ Note, however, comments by McDonald, supra note 86, who argues that "[a]mbiguity over the extent of legal obligation acknowledged within such policy initiatives allows a State to take risks in pursuing policy goals without feeling bound by having to undertake a specific course of conduct." This provides no real added flexibility, however, and ignores the fact that while they may not feel bound, the legal framework makes them bound.

${ }^{88} \mathrm{ARS}$, supra note 46 , at $65-67$.

${ }^{89}$ See Bosnia Genocide Case, 2007 I.C.J. at 432.

${ }^{90}$ See ARS, supra note 46, at 66 (commenting on Art. 16, 5).

${ }^{91}$ Vladyslav Lanovoy, Responsibility for Complicity in an Internationally Wrongful Act: Revisiting a Structural Norm 11, SHARES CONFERENCE (Nov. 17-18, 2011).
} 
state's speech, even though it has specific knowledge about an impending assassination of the foreign head of state. ${ }^{92}$ According to the Commentaries to Article 16, the requirement of "knowledge of the circumstances of the internationally wrongful act" is a relatively strict test, in that what is required is that "the relevant State organ intended, by the aid or assistance given, to facilitate the occurrence of the wrongful conduct." ${ }^{93}$ Referring also to Lowe, ${ }^{94}$ who argues that a state is complicit when it deliberately fails to inquire into the circumstances of an assisted act where there are clear indications that its assistance would be employed unlawfully, Jackson agrees that "wilful blindness, narrowly interpreted, is [also] a justified extension to the category of legal knowledge." 95 Similarly, Moynihan has argued that, while willful blindness should be applied with caution, "where the evidence stems from credible and readily available sources, such as court judgments, reports from fact-finding commissions, or independent monitors on the ground, it is reasonable to maintain that a State cannot escape responsibility under Article 16 by deliberately avoiding knowledge of such evidence." 96

The relevance of the concept of willful blindness to the knowledge requirement of Article 16 of the Articles on the Responsibility of States brings to the fore the procedural aspects of due diligence practice. A state or other duty holder that refrains from embarking on a reasonable inquiry into the factual circumstance underpinning certain risks may be found to be willfully blind. In this sense, the failure to exercise due diligence may contribute to a finding of responsibility for aiding or assisting in the commission of an internationally wrongful act.

\section{E. European Union and United Kingdom Cooperation with Libya}

\section{The European Union}

\section{EU Support to Libya in the Area of Migration Control}

As part of the policies of non-entrée, ${ }^{97}$ the EU and its member states have adopted policies having the result of preventing or significantly reducing access to the EU for some migrants and asylum-seekers. These are given clear expression in the 2017 Malta Declaration and Valletta Action Plan, ${ }^{98}$ much of which focuses on increasing collaboration with Libya and other North African and sub-Saharan countries on the "central Mediterranean migration route." 99 Other expressions of this policy approach include the EU-Turkey Statement, in which Turkey agreed to take back migrants reaching Greece irregularly and take back irregular migrants intercepted in Turkish waters, ${ }^{100}$ and the "Khartoum process," which is an agreement between the EU and the Horn of Africa migration route states which serves to curb migration to Europe. ${ }^{101}$

The EU has established several missions under its Common Foreign and Security Policy to tackle migrant smuggling and trafficking and strengthen security and border management. Relevant to Libya, these include the European Border and Coast Guard Agency (Frontex), ${ }^{102}$

\footnotetext{
${ }^{92}$ See Miles Jackson, Complicity in International Law 157 (2015).

${ }^{93} \mathrm{ARS}$, supra note 46, at 66 (commenting on Art. 16, 5).

${ }^{94}$ See Vaughan Lowe, Responsibility for the Conduct of Other States, 101 JAPANESE J. INT'L L. 1, 10 (2002).

${ }^{95}$ JACKSON, supra note 92, at 162.

${ }^{96}$ Harriet Moynihan, Aiding and Assisting: The Mental Element Under Article 16 of the International Law Commission's Articles on State Responsibility, 67 INT'L \& COMP. L.Q. 455, 462 (2018).

${ }^{97}$ See Gammeltoft-Hansen \& Hathaway, supra note 3.

${ }^{98} \mathrm{See}$ Press Release, Council of the European Union, Malta Declaration by the Members of the European Council on the External Aspects of Migration: Addressing the Central Mediterranean Route (Feb. 3, 2017).

${ }^{99} I d$.

${ }^{100}$ See Press Release, Council of the European Union, EU Turkey Statement (Mar. 18, 2016).

${ }^{101}$ See Declaration of the Ministerial Conference of the Khartoum Process (EU-Horn of Africa Migration Route Initiative), Khartoum Process (Nov. 28, 2014).

${ }^{102}$ See Origin \& Tasks, Frontex, https://frontex.europa.eu/about-frontex/origin-tasks/.
} 
Operation Sophia, ${ }^{103}$ which conducts surveillance activities by air and provides support to the Libyan Coastguard and Navy, ${ }^{104}$ and the EU Border Assistance Mission to Libya, which provides border management services as well as advice and capacity building on migration and border security. ${ }^{105}$ Connected to this is the support to help establish a Joint Rescue Coordination Centre in Libyan territorial waters, ${ }^{106}$ which was crucial to the designation of a Libya search and rescue region under international maritime law, and thus a pre-condition for Libya's assertion of a primary search and rescue function - in lieu of Italy or other EU member states. This has led boats in distress to be sent on to Libyan counterparts, resulting in interceptions by Libyan Coast Guards, and with the passengers then taken to Libyan detention centers. ${ }^{107}$

EU funding in the areas of migration, asylum, and border management is assured through a web of instruments and programs, including the EU Development Cooperation Instrument and the European Development Fund. ${ }^{108}$ In addition, the EU has established partnerships under the "European Agenda on Migration," with funds coming from the EU Emergency Trust Fund for Africa, which is a pooled fund of different EU funding instruments. ${ }^{109}$ This has been an important injection of funds, including to Libya, though some like Oxfam have criticized that "some of its projects respond to a European political sense of urgency to stop irregular migration to Europe." 110 Oxfam argued that the Fund "must adopt clearer procedures and more transparent and consultative processes to ensure that short-term interests do not jeopardize the long-term objectives of development, stability, poverty eradication and the protection of rights." 111 Kipp has also raised the lack of transparency of the fund, which operates mainly outside of parliamentary oversight. ${ }^{112}$ Concerns have also been expressed that some components of the EU funded projects in Libya serve as "forms of aid and assistance to human rights violations" by Libyan state agents, ${ }^{113}$ and that development aid has been made conditional on recipients' cooperation in "reducing migratory flows, either by preventing people from leaving in the first place or by promptly accepting them back when returned from Europe." 114

\footnotetext{
${ }^{103}$ See Eur. External Action Service, Strategic Review on EUNAVFOR MED Operation Sophia, EUBAM Libya \& EU Liaison and Planning Cell, EEAS (2018) 835 (July 27, 2018).

${ }^{104}$ See Decision 2016/993, of the Council of 20 June 2016 Amending Decision 2015/778 on a European Union Military Operation in the Southern Central Mediterranean, 2016 O.J. (L 162) 18 (extending Operation Sophia). This mandate was later extended to December 31, 2018, with the additional task of, among others, monitoring the effectiveness of training provided to the Libyan Coast Guard. Decision 2017/1385, of the Council of 25 July 2017 Amending Decision 2015/778 on a European Union Military Operation in the Southern Central Mediterranean, 2017 O.J. (L 94).

${ }^{105}$ See Decision 2018/2009, of the Council of 17 Dec. 2018 Amending and Extending Decision 2013/233/CFSP of the European Union Integrated Border Management Assistance Mission in Libya, 2018 O.J. (L 322) 25.

${ }^{106}$ See Eur. Comm., EU Support on Migration in Libya EU, Emergency Trust Fund for Africa - North of Africa Window, (Dec. 2019), https://ec.europa.eu/trustfundforafrica/sites/euetfa/files/eutf-factsheet_libya_dec_2019_1.pdf (providing an infographic on EU Cooperation on Migration in Libya). See also Eur. External Action Service (EEAS), EU-Libya Relations (Nov. 9, 2018), https://eeas.europa.eu/headquarters/headquarters-homepage_en/19163/EU-Libya\%20relations.

${ }^{107}$ See Sundersland \& Saleh, supra note 26, at 14.

${ }^{108}$ See Leonhard den Hertog, Money Talks Mapping the Funding for EU External Migration Policy, CEPS PAPER IN LIBERTY AND SECURITy IN Europe, No. 95 (Nov. 2016).

${ }^{109}$ See Eur. Comm., Decision on the Establishment of a European Union Emergency Trust Fund for Stability and Addressing Root Causes of Irregular Migration and Displaced Persons in Africa, C(2015)7293 (Oct. 20, 2015).

${ }^{110}$ Elise Kervyn \& Raphael Shihav, An Emergency for Whom? The EU Emergency Trust Fund for Africa-Migratory Routes and Development Aid in Africa, 4 OXford COMmitTeE For FAMINE Relief 2 (Nov. 2017).

${ }^{111} I d$. at 2.

${ }^{112}$ See David Kipp, From Exception to Rule: The EU Trust Fund for Africa, Stiftung Wissenschaft und Politik Research Paper, GER. INST. FOR INT'L \& SEC. AFF. (Dec. 2018).

${ }^{113}$ See Thomas Spijkerboer \& Elies Steyger, European External Migration Funds and Public Procurement Law, 4 EUROPEAN PAPERS 493, 515-16 (2019).

${ }^{114}$ Daria Davitti \& Annamaria La Chimia, A Lesser Evil? The European Agenda on Migration and the Use of Aid Funding for Migration Control, 10 IRISH Y.B. INT'L L. (2015).
} 
According to a September 2019 statement by the EU,

as for migration and community stabilization related projects, the EU currently has a package in place worth close to $€ 355$ million through the EU Trust Fund for Africa to Libya covering 21 projects, implemented by UN agencies, EU Member States and NGOs. This makes the North of Africa Window of the EU Trust Fund for Africa the biggest EU contributor to Libya and the most important instrument for funding external and migration action in Libya since the inception of the Trust Fund. ${ }^{115}$

Among these, the EU has provided support to help address the conditions of Libyan immigration detention. Funds have also been directed to the Libyan Red Crescent to improve rights-based migration management and bring psychosocial support to populations in need, as well as to the International Centre for Migration Policy Development for similar purposes. The EU has also provided support to the IOM program for "voluntary humanitarian repatriation" from Libya to countries of origin. It has also provided financial support to a UNHCR Emergency Transit Mechanism to evacuate particularly vulnerable asylum seekers out of Libya-some to temporary transit centers-for onward resettlement. ${ }^{116}$ Programs like the European Neighbourhood Instrument, and the Instrument Contributing to Stability and Peace, have provided additional support to Libya in sectors such as civil society, governance, health, economy, youth and education, and support to the political process, security, and mediation activities.

\section{Inadequate EU Due Diligence Frameworks}

A European Parliament study concluded that "boat migrants faced human rights violations in various phases of their migratory process" ${ }^{117}$ yet the "primary aim of existing EU policies and actions still seems to be the protection of the borders against 'illegal' immigration and the return of illegally staying migrants, rather than the development of effective strategies to protect human rights of migrants and the saving of lives on the Mediterranean."118

In 2013, the UN Special Rapporteur on Migrants expressed his concern that "there is no oversight or systematic evaluation as to how the policies are implemented by individual European Union entities, or national authorities who are charged with implementing European Union law." ${ }^{119}$ Council of Europe Commissioner on Human Rights, Dunja Mijatović has called for transparency and accountability in external migration cooperation. She called on European states to:

[C]arry out and publish a thorough analysis of any such proposals, looking at their potential impact on the rights of migrants, asylum seekers and refugees, and if necessary they should explicitly set out which measures they will take to avoid adverse impact. If the analysis shows serious threats for the protection of human rights, which cannot be prevented, the proposal should be withdrawn. ${ }^{120}$

\footnotetext{
${ }^{115}$ Presidency Conclusions, Libya and the Surrounding Area: Current Situation and Need for Immediate Action, Brussels European Council 11538/19 (Sept. 4, 2019).

${ }^{116}$ See Progress Report on the Implementation of the European Agenda on Migration, at 6, COM (2019) 126 final (Mar. 6, 2019).

${ }^{117}$ Eur. Parl., Migrants in the Mediterranean: Protecting Human Rights, 59, EP/EXPO/B/DROI/2015/01 (Oct. 29, 2015).

${ }^{118} I d$. at 60 .

${ }^{119}$ François Crépeau, Special Rapporteur on the Human Rights of Migrants, Regional Study: Management of the External Borders of the European Union and its Impact on the Human Rights of Migrants, 38, U.N. Doc. A/HRC/23/46 (Apr. 24, 2013).

${ }^{120}$ Council of Europe Comm'r on Human Rights, European States Must Put Human Rights at the Centre of Their Migration Policies (July 5, 2018), https://www.coe.int/en/web/commissioner/-/european-states-must-put-human-rights-at-the-centreof-their-migration-policies.
} 
She has also called on cooperating states to carry out independent and effective monitoring to assess compliance with human rights norms. ${ }^{121}$

The Charter on Fundamental Rights applies principally to "the institutions, bodies, offices and agencies of the Union." 122 Accordingly, in addition to general principles of EU law concerning good administration, proportionality, and legal certainty, the respect for human rights is a condition for the legality of EU action. ${ }^{123}$ In this sense there are arguably dual obligations on the EU to both exercise due diligence to ensure that its programs do not result in human rights violations abroad, ${ }^{124}$ and to fully apprise itself of the operational context in the countries in which it provides aid and assistance, in order to ensure that it is not willfully ignoring human rights violations facilitated through its programmatic work. In this respect, citing the Charter on Fundamental Rights, the European Commission has adopted operational guidance on taking account of fundamental rights in Commission Impact Assessments ${ }^{125}$ because "[f]undamental rights enshrined in the Charter are not mere abstract values or ethical considerations. Respect for fundamental rights is a legal requirement, subject to the scrutiny of the European Court of Justice. Respect for fundamental rights is a condition of the lawfulness of EU acts." 126 This includes methodological steps for examining different policy options that may affect human rights.

Overall, EU due diligence frameworks are not sufficiently transparent or robust to satisfy due diligence human rights obligations. The decision on commencement or extension of the mandates of Common Foreign and Security Policy and Common Security and Defence Policy missions is taken by the EU Council Political and Security Committee, yet, opaque document management and access rules makes the decision-making accountability trail difficult to trace. ${ }^{127}$ The risk management process that underpins those decisions is not fully accessible.

EU Emergency Trust Fund for Africa programming is set out in some detail on its website. ${ }^{128}$ Each assistance program is listed, the largest of which is " $[\mathrm{m}]$ anaging mixed migration flows in Libya through expanding protection space and supporting local socio-economic development," a $€ 90$ million project. It was adopted in April 2017 and contains an action fiche that explains the objectives, background and context, and a detailed description. ${ }^{129}$ It also sets out a risk matrix. ${ }^{130}$ Among the risks identified, the last to be mentioned is "[h] uman rights violations in the areas related to the action's field of intervention increase." This is assessed as having a risk level of medium. As a mitigating measure, it is noted that "the Action is driven by a rights based approach and the conflict sensitivity is mainstreamed in all the activities." There is no information on how the risk or the mitigation measure were assessed, how often they are due to be assessed, or the criteria for the assessment.

\footnotetext{
${ }^{121}$ See id.

${ }^{122}$ Charter of Fundamental Rights of the European Union art. 51(1), Dec. 7, 2000, 2010 O.J. (C 83) 389 (entered into force Dec. 1, 2009).

${ }^{123}$ See Treaty on European Union (TEU) arts. 6(3), 21(3) [Consolidated Versions of the Treaty on European Union and the Treaty on the Functioning of the European Union (TFEU), 2010 O.J. (C 83), 2012 O.J. (C 326)]. See also ECJ, Case C294/83, Les Verts v. Eur. Parl., ECLI:EU:C:1986:166, Judgment of 23 Apr. 1986.

${ }^{124}$ Note, however, that this perspective on the jurisdictional reach of the European Convention is controversial. See infra Section D.I.2.

${ }^{125}$ See Eur. Comm., supra note 80.

${ }^{126}$ Eur. Comm., supra note 80 , at 4.

${ }^{127}$ E.U. Ombuds., Decision in case 935/2018/EA on the Handling of Requests for Public Access to EUNAVFOR Med Operation Sophia's documents, Case No. 935/2018/FP (July 22, 2019).

${ }^{128}$ See EU Support on Migration in Libya EU, Emergency Trust Fund for Africa - North of Africa Window (Dec. 2019), https://ec.europa.eu/trustfundforafrica/sites/euetfa/files/eutf-factsheet_libya_dec_2019_1.pdf (Infographic on EU Cooperation on Migration in Libya).

${ }^{129}$ Eur. Comm., Managing Mixed Migration Flows in Libya Through Expanding Protection Space and Supporting Local Socioeconomic Development (Apr. 12, 2017).

${ }^{130}$ See id. at $18-19$.
} 
The project "Support to Integrated Border and Migration Management in Libya-First Phase," which involves training and support to the Libyan Coast Guard, concedes that the risks associated with the project are "unusually high," and consequently, "the program will include solid monitoring measures and a number of risk mitigating actions, as well as solid and factual information sharing. It will begin with a substantive baseline assessment and analysis, drawing on existing sources, to guide a conflict sensitive approach." Nevertheless, mitigation measures are limited and there is no consideration of whether and how decisions on ending assistance can be taken and actioned, should the risks become too great. ${ }^{131}$ Similarly, the project entitled "Integrated Approach to Protection and Emergency Assistance to Vulnerable and Stranded Migrants in Libya," which outlines support to detention centers and for returns, provides a clear contextual assessment of the challenges, but only minimal risk and risk mitigation strategies. The main mitigation strategy is to continuously monitor the political situation and maintain positive relationships with Libyan officials. ${ }^{132}$

For EU operational missions such as Frontex and Operation Sophia, oversight frameworks have in principle become more robust following initial expressions of concern, ${ }^{133}$ though oversight focuses on ongoing human rights assessment as opposed to risk analysis prior to the taking of decisions to act or engage in projects. In March 2012, the European Ombudsman initiated an inquiry into Frontex operations and underscored the importance of granting effective access to a complaints mechanism for persons individually affected by rights infringements and also in the public interest. ${ }^{134}$ The Ombudsman also initiated an inquiry into the means through which Frontex ensures respect for fundamental rights in joint return operations. ${ }^{135}$

The EU Court of Auditors also provides some external oversight of EU spending. ${ }^{136}$ This helps to ensure that EU funds are used in line with intended objectives and helps to improve the effectiveness of EU financial management, though human rights considerations are not a primary focus. The Court is free to decide on what it will audit, how audits are carried out, and how and when to present its findings. Special Reports are not binding, but they receive a formal response by the EU institution under review. A 2016 Special Report considering projects involved in tackling "irregular" migration raised concerns about certain projects' lack of precautionary measures to guarantee respect for migrants' rights, and an absence of thinking about machinery for responding to human rights violations. ${ }^{137}$

The EU Fundamental Rights Agency produces annual human rights reports as well as thematic reports, opinions, and briefings relating to migration matters. The bulk of its work focuses on the conduct of member states in the territory of the EU, but several of its initiatives touch on extraterritorial conduct. For example, it carried out research and published recommendations on NGO

\footnotetext{
${ }^{131}$ Eur. Comm., Support to Integrated Border and Migration Management in Libya - First Phase, at 14-15.

${ }^{132}$ Eur. Comm., Integrated Approach to Protection and Emergency Assistance to Vulnerable and Stranded Migrants in Libya, at 14 .

${ }^{133}$ See Amnesty Int'l, The Human Cost of Fortress Europe: Human Rights Violations against Migrants and Refugees at Europe's Borders, A.I. INDEX EUR 05/001/2014 (2014). See also Elspeth Guild et al., Implementation of the EU Charter of Fundamental Rights and its Impact on EU Home Affairs Agencies Frontex, Europol and the European Asylum Support Office, at 105, E.U. Doc. PE 453.196 (2011); Parl. Ass. Council of Europe, Frontex: Human Rights Responsibilities, Doc. 13161 (Apr. 8, 2013).

${ }^{134}$ See Eur. Ombuds., Decision Closing Own-Initiative Inquiry OI/5/2012/BEH-MHZ Concerning the European Agency for the Management of Operational Cooperation at the External Borders of the Member States of the European Union, 99 79-83, Frontex (Nov. 12, 2013).

${ }^{135}$ See Eur. Ombuds., Ensuring Respect for Fundamental Rights in Joint Operations for the Forced Return of Irregular Third-Country Migrants, OI/9/2014/MHZ (Oct. 20, 2014).

${ }^{136}$ See TEU, supra note 123, at 170 (Art. 287).

${ }^{137}$ See Eur. Ct. of Aud., EU External Migration Spending in Southern Mediterranean and Eastern Neighbourhood Countries until 2014, Special Report No. 9, 989 (2016).
} 
ships involved in search and rescue in the Mediterranean, ${ }^{138}$ and has produced opinions on the European Border and Coast Guard Regulation ${ }^{139}$ and the proposal for an EU common list of safe countries of origin, ${ }^{140}$ as well as guidance on how to reduce the risk of refoulement in external border management. ${ }^{141}$ Nonetheless, the Agency does not have a direct oversight or advisory role; its opinions are simply recommendatory. Its guidance on how to reduce the risk of refoulement in external border management when working in or together with third countries ${ }^{142}$ recommends that EU member states should "conduct a careful assessment of the human rights situation" in the recipient country when considering whether to deploy experts or liaison officers to third countries, or where operational cooperation with a third country is envisaged, which may involve the interception of migrants or their disembarkation in a third country. Such an assessment "would enable EU Member State to evaluate possible fundamental rights implications and calibrate its planned activities so as to avoid or reduce the risk of participation in conduct which could violate human rights." ${ }^{143}$ It has also recommended that "third countries should not be requested to intercept people on the move before they reach the EU external border, when it is known or ought to be known that the intercepted people would as a result face persecution or a real risk of other serious harm." ${ }^{\text {"44 }}$

In principle, following the Lisbon Treaty, the actions of Frontex and Operation Sophia could be subject to proceedings before the Court of Justice of the EU (CJEU). If it had jurisdiction, the CJEU could review the legality of Frontex acts, annul them if it had acted unlawfully, ${ }^{145}$ and rule on allegations relating to the failure to act ${ }^{146}$ or inappropriate action taken. ${ }^{147}$ Nevertheless, it would be difficult to attribute conduct to Frontex given its primary role of coordinating member states' actions. Also, the CJEU has minimal jurisdiction over acts adopted within the EU's Common Foreign and Security Policy, ${ }^{148}$ apart from sanctions. ${ }^{149}$ Accountability is thus extremely restricted for the EU's external border control and migration actions. Consequently, to date, claims have focused on state responsibility under the European Convention on Human Rights. ${ }^{150}$

\section{United Kingdom Support to Libya}

The UK military helped rebel forces to topple Muammar Gaddafi's regime in the 2011 Civil War. Thereafter, it has provided support, mainly through the Department for International Development and the Conflict, Stability and Security Fund, for reconstruction and the strengthening of state institutions. ${ }^{151}$

\footnotetext{
${ }^{138}$ See E.U. Agency for Fund. Rights, 2019 Update - NGO Ships Involved in Search and Rescue in the Mediterranean and Criminal Investigations (June 2019).

${ }^{139}$ See E.U. Agency for Fund. Rights, The Revised European Border and Coast Guard Regulation and its Fundamental Rights Implications, Opinion 5/2018 (Nov. 27, 2018).

${ }^{140}$ See E.U. Agency for Fund. Rights, Opinion Concerning an EU Common List of Safe Countries of Origin, Opinion 1/2016 (Mar. 23, 2016).

${ }^{141}$ See E.U. Agency for Fund. Rights, Guidance on How to Reduce the Risk of Refoulement in External Border Management when Working in or Together with Third Countries (Dec. 2016). See also E.U. Agency for Fund. Rights, Scope of the Principle of Non-Refoulement in Contemporary Border Management: Evolving Areas of Law (Dec. 2016).

${ }^{142}$ See E.U. Agency for Fund. Rights, Guidance on How to Reduce the Risk of Refoulement in External Border Management when Working in or Together with Third Countries (Dec. 2016).

${ }^{143} I d$. at 2.

${ }^{144} I d$. at 3 .

${ }^{145}$ TFEU arts. 263, 265.

${ }^{146}$ See TFEU, supra note 123, at 164 (discussing art. 267); SECURITY Versus JusticE?: POliCE AND JUdiCIAL COOPERATION IN THE European UNiON 44 (Elspeth Guild \& Florian Geyer eds., 2008).

${ }^{147}$ See Melanie Fink, The Action for Damages as a Fundamental Rights Remedy: Holding Frontex Liable, in this issue.

${ }^{148}$ See TEU art. 24(4); TFEU art. 275.

${ }^{149}$ TFEU art. 275.

${ }^{150}$ See S.S. v. Italy, App. No. 21660/18 (pending on Nov. 11, 2019).

${ }^{151}$ See Foreign Affairs Comm., Libya: Examination of Intervention and Collapse and the UK's FUture Policy Options: Third Report of SESSION, 2016-17, HC 119 (UK).
} 
In the area of migration control, UK support has focused on facilitating migrants' voluntary return to their countries of origin, training the Libyan Coast Guard, promoting economic opportunities, tackling conflict in countries of origin, and confronting the exploitation of vulnerable people by smugglers and traffickers. It had also funded UN agencies working in Libyan detention centers, which it had previously funded directly, ${ }^{152}$ and has supported UNHCR to build and open a new Gathering and Departure Facility in Tripoli to aid with resettlement. ${ }^{153}$ These and other measures such as deploying Navy ships and staff to assist with Operation Sophia and Frontex's Operation Triton, its chairmanship of the Khartoum Process, and its active support of the EU Emergency Trust Fund for Africa, are undertaken in close collaboration with European partners and in pursuit of agreed EU policy. ${ }^{154}$

Some of the above measures have generated criticism from civil society groups and policy experts. ${ }^{155}$ One main concern is that support to detention centers with dire conditions ensures their continued operation. Another is that training of the Libyan Coast Guard has helped to have a Libyan Search and Rescue zone recognized internationally. ${ }^{156}$ This increases the prospect that vulnerable individuals are placed in the hands of persons who have been responsible for torture and ill-treatment and who have colluded with smugglers, ensuring that migrants continue to face ill-treatment in detention. Support to the voluntary return scheme in a context in which migrants have no other choice but to return to inhuman detention facilities with a real risk of further human rights violations, arguably contributes to and provides support for a form of collective expulsion or refoulement. ${ }^{157}$

\section{Overseas Security and Justice Assistance Guidance}

Overseas Security and Justice Assistance (OSJA) assessments have become part of the practice of the UK's overseas support particularly in conflict-affected countries, ${ }^{158}$ such as Libya. The guidance helps mitigate legal, policy, or reputational risks where it is assessed that there is a serious risk that the assistance-whether case-specific or longerterm capacitybuilding-might directly or significantly contribute to a violation of human rights or international humanitarian law. It applies to all new proposed overseas security and justice assistance projects, as well as extensions to existing assistance and where a substantial change in circumstances has significantly altered the risk for existing assistance. It also applies to all departmental and agency leads, including where the engagement is undertaken by external agencies on behalf of a department or agency with UK funding or endorsement. ${ }^{159}$

\footnotetext{
${ }^{152}$ See Foreign Affairs Comm., Finding a Diplomatic Route: European Responses to Irregular Migration INQUIRY, WRITTEN EVIDENCE FROM LAWYERS FOR JUSTICE IN LIBYA (ERM0009), paras. 25, 26 (May 7, 2019) (UK).

${ }^{153}$ See Foreign Affairs Comm., Finding a Diplomatic Route: European Responses to Irregular Migration Inquiry, Written EVIDENCE from the Foreign AND COMmonweAlth OfFice (ERM0006) (Apr. 24, 2019) (UK).

${ }^{154}$ See id. See also Foreign Affairs Comm., Libya: Examination of Intervention and Collapse and the UK's Future Policy Options, Government Response to the Committee's Third Report of Session, 2016-17, HC 834, at 9-10 (UK).

${ }^{155}$ See Foreign Affairs Comm., Finding a Diplomatic Route: European Responses to Irregular Migration INQUiRy, WritTEN EVIDENCE FROM SAFERWORLD (ERM0012) (July 9, 2019) (UK); Foreign AfFaIRS COMM., supra note 152; Foreign AfFairs Comm., Finding a Diplomatic Route: European Responses to Irregular Migration INQUiRY, WritTEN EVIDENCE FROM AMNESTy INTERNATIONAL UK (ERM0013) (July 9, 2019) (UK); ForEIGN AfFAIRS Comm., Finding a Diplomatic Route: European Responses to Irregular Migration Inquiry, Written Evidence From Dr. MariagiUlia GiUfFré (ERM0010) (May 7, 2019) (UK).

${ }^{156}$ See Sundersland \& Saleh, supra note 26 , at 14.

${ }^{157}$ See Julien Brachet, Beyond War and Peace: the IOM and International Migration Control in Libya (International Migration Institute, University of Oxford, Working Paper No. 124, Dec. 2015). See also Felipe González Morales (Special Rapporteur on the Human Rights of Migrants), Rep. on the Human Rights of Migrants, g9 15, 30, U.N. Doc. A/HRC/38/ 41 (May 4. 2018).

${ }^{158}$ See UK Stabilisation Unit, The UK Government's Approach to Stabilisation: A Guide for Policy Makers and Practitioners, at 80, para. 57 (Mar. 2019).

${ }^{159}$ See UK Gov’t, Overseas Security and Justice Assistance (OSJA) Human Rights Guidance 5, g 8 (2017).
} 
Unlike the US equivalent that prohibits the Departments of State and Defense from providing military assistance to foreign security force units that violate human rights, ${ }^{160}$ OSJA is not enshrined by legislation - it is simply policy guidance. Its "bite" is therefore much weaker, though its scope is broader. The UK Government first put in place OSJA guidance in 2011. It was revised in 2014 and again in 2017. ${ }^{161}$

There are four stages to the assessment. First, the situation in the recipient country is assessed. Second, the human rights, international humanitarian law, political, and reputational risks associated with the proposed assistance are identified. Third, consideration is given to how to mitigate the risks, or indeed whether the risks can be mitigated. Fourth, an overall assessment is made as to whether there is a serious risk that the assistance might directly or significantly contribute to a violation of human rights or international humanitarian law or lead to a reputational or political risk that cannot be mitigated. If so, senior personnel or Ministers would need to approve the assessment. ${ }^{162}$ The Guidance specifies that an assessment must be made prior to the provision of any assistance. It also gives examples of risk mitigation measures.

On its face, the guidance sets out a robust process for risk analysis. Nevertheless, there are several problems.

First, if "there is a serious risk that the assistance might directly or significantly contribute to a violation of human rights and it is assessed that the mitigation measures will not effectively mitigate this risk," the guidance indicates that to proceed, such cases require ministerial approval. ${ }^{163}$ Such assistance is not automatically stopped, which undermines the process. This point was raised by the Independent Commission on Aid Impact: "[T]here should be a willingness not just to delay, but also to cancel programmes if the risk of human rights violations or other harm is high and cannot be effectively mitigated." 164

Second, the guidance lists diplomatic assurances as a key means by which risk can be mitigated; assurances are listed as mitigation strategies for risks relating to the death penalty, torture and other cruel, inhuman or degrading treatment or punishment, extrajudicial killings, and fair trials. Yet, the guidance does not specify a baseline standard that assurances must be credible and trustworthy, nor does it explain how assurances received should be assessed, which gives the impression they are "pro forma." Furthermore, it is specified that "where possible," assurances should be in place before the assistance is provided. ${ }^{165}$ Thus, pre-implementation assessments are not automatic.

Third, another mitigation measure set out in the guidance is human rights training. But, training-based solutions may not always be convincing, as they assume-sometimes wrongly - that violations are the result of a knowledge deficit on the side of the people to be trained. ${ }^{166}$

Finally, completed risk assessments are not in the public domain and summary information is difficult to access. ${ }^{167}$ Freedom of information act requests have not overcome the transparency gaps, the bulk of them rejected on national security or international relations grounds. ${ }^{168}$ Even

\footnotetext{
${ }^{160}$ See Leahy Law, 22 U.S.C. $\$ 2378$ d (2012) (limitation on assistance to security forces).

${ }^{161}$ See UK Gov'T, supra note 159.

${ }^{162}$ See id. at 21.

${ }^{163}$ See id. at 16.

${ }^{164}$ Independent Commission for Aid Impact (ICAI), ICAI Follow-Up of: The UK's Aid Response to Irregular Migration in the Central Mediterranean: A Summary of ICAI's Full Follow-Up Review, at 2 (June 2018).

${ }^{165}$ See UK Gov'T, supra note 159, at 21.

${ }^{166}$ See ICAI, The Conflict, Stability and Security Fund's Aid Spending: A Performance Review, para. 4.69 (Mar. 2018).

${ }^{167}$ See Letter from The Rt Hon David Lidington, CBE MP, to the Joint Committee on National Security Strategy (2019), http://data.parliament.uk/writtenevidence/committeeevidence.svc/evidencedocument/national-security-strategy-committee/ conflict-stability-and-security-fund-annual-report-201718/written/94983.html.

${ }^{168}$ See Reprieve \& Bahrain Institute for Rights and Democracy, Training Torturers: The UK's Role in Bahrain's Brutal Crackdown on Dissent, at 73-75 (2018).
} 
a request for statistics on the number of OSJA assessments completed for specific projects was rejected, surprisingly in the internet age, because "information on the number of OSJA assessments completed in previous years and a more detailed breakdown of applications requiring Ministerial approval is not held centrally and could only be obtained at a disproportionate cost."169 To date, there has been only limited parliamentary scrutiny, mainly by the Foreign Affairs Committee, by questions posed by interested Members of Parliament and within thematic inquiries on related topics. OSJA processes have also been reviewed by the Independent Commission on Aid Impact, which reports to Parliament. ${ }^{170}$ Public scrutiny is virtually non-existent.

\section{OSJA Processes Regarding Libya Support}

In 2017, the Independent Commission for Aid Impact expressed concern that there was no evidence that an OSJA risk assessment had been undertaken prior to the initiation of support to the Libyan Coast Guard. ${ }^{171}$ It went on to underscore that " $[\mathrm{w}]$ hile the government informed us that as this was a contribution to an EU project it would be sufficient to rely on EU assessment systems, we were not provided with information about these systems or evidence that the analysis had been fed into project design." 172 In response, the Government explained that a risk assessment on an IOM Libya project was conducted in October 2016, "[t]his recognised the risks and mitigation procedures associated with operating in the country but concluded that 'there is less than a serious risk that this project may directly or significantly contribute to a violation of human rights."'173 It was also specified that the UK's funding of training to the Libyan Coast Guard and Navy was vetted through OSJA processes. ${ }^{174}$ An assessment was also carried out in relation to the training of Libyan soldiers at Bassingbourn camp, in the UK. ${ }^{175}$

Efforts by the public to obtain details about OSJA risk assessments and mitigation plans have not been fruitful. A freedom of information act request to the Department for International Development about the UK's involvement in training the Libyan Coast Guard was largely rejected for reasons pertaining to international relations, ${ }^{176}$ despite a recognized public interest in disclosure. ${ }^{177}$ This rejection was upheld on appeal, ${ }^{178}$ with only limited analysis as to whether maintaining the exemption was the least restrictive way to preserve international relations, and no consideration of what information of relevance was already in the public domain about Libya and the EU. ${ }^{179}$

It would be surprising if the OSJA process is, as has been suggested, "the most comprehensive and demanding tool of its type anywhere in the world." 180 The absence of any opportunity for public scrutiny militates against any possibility for it to be effective and seen to be so.

\footnotetext{
${ }^{169}$ U.K. House of Commons, International Assistance: Security, Foreign and Commonwealth OfFice Written QUESTION - ANSWERED ON 6 JUNE 2019, HC Deb. (June 6, 2019).

${ }^{170}$ See discussion supra Sections E.II.3, E.II.4.

${ }^{171}$ See ICAI, The UK's Aid Response to Irregular Migration in the Central Mediterranean: A Rapid Review, para. 4.41 (Mar. 2017).

${ }^{172} I d$. at 4.41 .

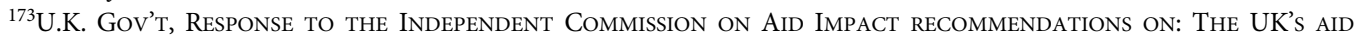
RESPONSE TO IRREGUlar Migration IN THE CENTRAL MEDiterRANEAN MARCh 2017, at 2 (Apr. 18, 2017).

${ }^{174} 19$ June 2019, Parl Deb HC (2019).

${ }^{175}$ U.K. House of COMmons, Libya: Written Question - 219659, Answered by Mr Mark Francois, THEN Minister of STAte (Ministry of Defence) (Mar. 3, 2015).

${ }^{176}$ Information Commissioner's Office (ICO), Decision, FS50733635 (Sept. 19, 2018). See Freedom of Information Act, c. 36, Art. 27 (Eng.).

${ }^{177} \mathrm{~A}$ public interest in disclosure was recognized but, in accordance with the qualified nature of Art. 27 FOIA, it was not judged to outweigh the public interest in maintaining the exemption.

${ }^{178}$ Information Commissioner's Office (ICO), Decision, FS50733635 (Sept. 19, 2018).

${ }^{179} I d$. at 22 .

${ }^{180}$ U.K. House of Commons, OSJA GuidanCE: WritTen STATEMENT HCWS441 (Jan. 26, 2017).
} 


\section{Independent Commission for Aid Impact}

The Independent Commission for Aid Impact is an independent body reporting to Parliament that works to improve the quality of UK development assistance through "robust, independent scrutiny." 181 In its 2018 assessment of Conflict, Stability and Security Fund aid programming-in which it gave an overall review score of amber-red, ${ }^{182}$ it noted in respect of the sample of OSJA assessments it had reviewed:

Several OSJAs were produced after programming had commenced and some OSJAs were incomplete or of low quality (typically with a stronger analysis of the UK's reputational risks than of the risk of ... support aggravating human rights violations) or had not been conducted at all. The human rights assessments within our sample always gave the green light for the proposed activity, without requiring any design modifications. This ... raises a concern as to whether these assessments are an effective control mechanism. ${ }^{183}$

The Commission recommended that this programming "should demonstrate more clearly and carefully how they identify, manage and mitigate risks of doing harm." ${ }^{\text {" }}$ "It also found that while the funding has considered the risks associated with legitimizing or otherwise becoming complicit in violations, it "has a high risk appetite. In our case studies we only came across one decision not to work with an institution because of its human rights record." ${ }^{185}$ Nevertheless, the Commission determined this risk to be "appropriate, within reason," given that it is impossible to address conflict without involving the government. ${ }^{186}$ This is a sweeping statement, however, and it implies that addressing conflict while ignoring human rights violations is somehow possible and an appropriate role for a foreign government, and that "doing no harm" by deciding not to engage is never going to be appropriate.

The Independent Commission on Aid Impact carried out a narrowly focused review on UK aid's response to irregular migration in the central Mediterranean, ${ }^{187}$ a part of which focused on aid to Libya and to partners working in Libya. It expressed concern about training the Libyan Coast Guard, which "delivers migrants back to a system that leads to indiscriminate and indefinite detention and denies refugees their right to asylum." 188 It also expressed concern that there was no evidence that an OSJA risk assessment had been undertaken prior to training. ${ }^{189}$ Similarly, it found the assessment of the system of detention centers inadequate, particularly to assess the requirements of the "do no harm" principle. ${ }^{190}$

The Government's response to these concerns appears to be twofold: First, on support provided through EU channels, it relied on the EU's own risk mitigation processes. The Independent Commission on Aid Impact expressed concern about that approach. ${ }^{191}$ Certainly it would not insulate the UK from potential allegations of complicity or lack of due diligence, if the EU assessment processes were judged to be deficient. ${ }^{192}$ Second, on the Government's own methodologies,

\footnotetext{
${ }^{181}$ ICAI, The Conflict, Stability and Security Fund's Aid Spending: A Performance Review, at 2 (Mar. 2018).

${ }^{182} \mathrm{See}$ id. Amber-red refers to "Unsatisfactory achievement in most areas, with some positive elements. An area where improvements are required for UK aid to make a positive contribution."

${ }^{183} \mathrm{Id}$. at 4.70 .

${ }^{184} \mathrm{Id}$. at iv.

${ }^{185} I d$. at 4.68 .

${ }^{186} \mathrm{Id}$.

${ }^{187}$ See ICAI, The UK's Aid Response to Irregular Migration in the Central Mediterranean: A Rapid Review (Mar. 2017).

${ }^{188} \mathrm{Id}$. at 4.41 .

${ }^{189}$ See id.

${ }^{190} \mathrm{Id}$.

${ }^{191}$ See id. at 4.41 ("While the government informed us that as this was a contribution to an EU project it would be sufficient to rely on EU assessment systems, we were not provided with information about these systems or evidence that the analysis had been fed into project design.").

${ }^{192}$ See Section E.I.2 on the EU's risk assessment and mitigation processes.
} 
it appears to take an overly narrow approach to risk. It indicates, in relation to the IOM project assessment, that "there is less than a serious risk that this project may directly or significantly contribute to a violation of human rights." 193

Overall, the Government accepted the main recommendations on risk assessment and mitigation to do no harm, but it did so by indicating it was already acting in the ways recommended. While this indication is not altogether accurate, the added scrutiny resulting from the Independent Commission on Aid Impact engagement has been important.

\section{The Role of Parliament}

Each year, the Parliament's Foreign Affairs Committee reviews the Foreign and Commonwealth Office's Annual Report on Human Rights, which contains a small section with summarized information on OSJA assessments. In addition to these annual reviews, in 2016, the Foreign Affairs Committee initiated a thematic inquiry into the UK's intervention in Libya, the country's collapse, and the UK's future policy options. Its inquiry report ${ }^{194}$ included a section on migration, including a part on the UK's policy statement on preventing migrant deaths: 195 "We do not support planned search and rescue operations in the Mediterranean. We believe that they create an unintended 'pull factor', encouraging more migrants to attempt the dangerous sea crossing and thereby leading to more tragic and unnecessary deaths." 196 The Committee recommended that "the FCO must set out and re-examine the evidence base underpinning its assertion." 197 In response, the Government justified its approach in light of its consistency with wider EU policy. ${ }^{198}$ The Committee did not appear to have much influence in shaping or helping to evolve UK policy in this regard.

In 2019, the Foreign Affairs Committee initiated another inquiry to "explore ... what the UK, France and Italy are doing to police migration routes and to address the root causes of large scale displacement." 199 One of the focuses of the inquiry was on how the UK ensures it complies with current international legal obligations as regards its migrant policies and to what extent, and how, it factors in the protection of migrants' welfare in such policies and co-operation, including in connection with migrants in Libya. ${ }^{200}$ Many of those who provided evidence submitted that more robust scrutiny of support is needed to ensure compliance with human rights obligations. ${ }^{201}$ The inquiry report, issued 4 November 2019, agreed. It recommended that:

[T] he UK should put in place robust monitoring and safeguards to ensure that its funding to migration programmes in Libya is not contributing to abuses, as well as to strengthen protection for migrants in Libya, and should press its European partners to do the

\footnotetext{
${ }^{193}$ ICAI, Response to the Independent Commission on Aid Impact Recommendations on: The UK's Aid Response to Irregular Migration in the Central Mediterranean, March 2017, at 2 (Apr. 18, 2017).

${ }^{194}$ See Foreign Affairs Comm., Libya: Examination of Intervention and Collapse and the UK's Future Policy Options: ThiRd Report of SESSION, 2016-17, HC 119 (UK).

${ }^{195} \mathrm{Id}$. at 100 .

${ }^{196} I d$. at 101.

${ }^{197} I d$. at 105.

${ }^{198}$ See Foreign Affairs Comm., Libya: Examination of Intervention and Collapse and the UK's Future Policy Options, Government Response to the Committee’s Third Report of Session, 2016-17, HC 834, at 9-10 (UK).

${ }^{199}$ Foreign Affairs Comm., Finding a Diplomatic Route: European Responses to Irregular Migration InQuiry, 2019, HC 107 (UK).

${ }^{200}$ See id.

${ }^{201}$ See Foreign Affairs Comm., Finding a Diplomatic Route: European Responses to Irregular Migration

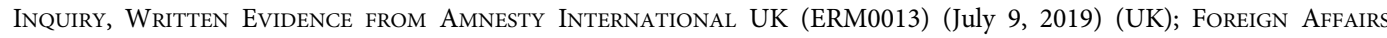
Comm., Finding a Diplomatic Route: European Responses to Irregular Migration Inquiry, Written Evidence From LAWYers fOr Justice In Libya (ERM0009), paras. 35, 36 (May 7, 2019) (UK); Foreign AfFairs Comm., Finding a Diplomatic Route: European Responses to Irregular Migration Inquiry, Written Evidence from SAFERWORLD (ERM0012) (July 9, 2019) (UK).
} 
same ... . In its response to this report, the Government should set out its assessment of how far human rights measures within its assistance to the Libyan Coastguard have improved this force's human rights performance, including actions taken, dates, and quantifiable measures. ${ }^{202}$

At the time of writing, the Government had not yet responded to the report.

\section{The Role of the Courts}

The lack of transparency of OSJA assessments and the seeming failure of the Government to take adequate measures in mitigation, or to contemplate a curtailment of support, has led to litigation. Under the Freedom of Information Act, it is possible to seek judicial review of Information Commissioner decisions refusing to release information in the public interest. While this is not known to have happened yet for assessments concerning Libya, there have been approaches to the courts that concern support provided to other countries. ${ }^{203}$

Judicial review proceedings can also be used to assess and potentially quash a decision to provide support. In this sense, litigation has been used to seek to hold the UK Government to its due diligence obligations. This was used in the Campaign Against Arms Trade case concerning alleged violations to the Armed Trade Treaty stemming from arms sales to Saudi Arabia. ${ }^{204}$ The applicants sought an injunction to prevent the Government from continuing to license the export of military equipment to Saudi Arabia on account of international humanitarian law abuses committed by Saudi coalition forces in Yemen. Section 9(3) of the Export Control Act of 2002 required the Secretary of State to give guidance about the general principles to be followed when exercising licensing powers. This resulted in the issuance of consolidated criteria, section 2(c) of which stipulates "not [to] grant a licence if there is a clear risk that the items might be used in the commission of a serious violation of international humanitarian law." 205 These consolidated criteria are distinct from, though raise similar issues to, the OSJA guidance. The claim was rejected by the High Court in 2017, but this decision was overturned on appeal. ${ }^{206}$ The appeals court held that the historic pattern of international humanitarian law breaches on the part of the coalitionand Saudi Arabia in particular — was central to the estimation of the risk of future violations. ${ }^{207}$ It went on to clarify:

If the result of historic assessments was that violations were continuing despite all such efforts, then that would unavoidably become a major consideration in looking at the "real risk" in the future. It would be likely to help determine whether Saudi Arabia had a genuine intent and, importantly, the capacity to live up to the commitments made. ${ }^{208}$

While there are not yet any known cases concerning support provided by the UK to Libya, there are murmurs that cases may come. The Guardian newspaper reported in 2018 that an Ethiopian teenager tortured in a Libyan migrant detention center that had received UK aid funding was intending to bring a claim against the Department for International Development. ${ }^{209}$ Similar

\footnotetext{
${ }^{202}$ Foreign AfFairs COMM., supra note 199, at 21.

${ }^{203}$ See, e.g., Nour v. Sec'y State Def. [2015] EWHC (Admin) 2695 (Eng.); El Gizouli v. Sec'y State Home Dep't [2019] EWHC (Admin) 60 (Eng.).

${ }^{204}$ See Campaign Against Arms Trade v. Sec'y State Int'l Trade [2017] EWHC (QB) 1726, and on appeal [2019] EWCA (Civ) 1020.

${ }^{205}$ Set out in Campaign Against Arms Trade v. Sec'y State Int'l Trade [2017] EWHC (QB) 1726 [8].

${ }^{206}$ See id. and, on appeal, [2019] EWCA (Civ) 1020. On July 9, 2019, leave was granted to take the matter to the Supreme Court. At the time of writing, the Supreme Court appeal was pending.

${ }^{207}$ See [2019] EWCA (Civ) 1020, 83. See also 2019] EWCA (Civ) 1020, gg 63, 138.

${ }^{208} I d$. at 144 .

${ }^{209}$ See Diane Taylor, Asylum Seeker to Sue UK for Funding Libyan Detention Centres, The GuARDIAN (Dec. 20, 2018), https://www.theguardian.com/uk-news/2018/dec/20/asylum-seeker-to-sue-uk-for-funding-libyan-detention-centres.
} 
efforts are underway elsewhere. An Italian court in Milan found that the Italian supported personnel of the Libyan reception centers torture and enslave the migrants hosted there. ${ }^{210}$ According to reports, another court in Rome found "push backs" by an Italian navy ship of Eritreans to Libya unlawful. ${ }^{211}$ In France, judicial review proceedings were lodged against a February 2019 decision of the French Government to supply six boats to the Libyan Coast Guard. ${ }^{212}$ The Paris Administrative Court rejected the request to suspend the boats' delivery, holding that the transfer was an appropriate exercise of France's foreign relations. This decision was appealed. Prior to the ruling of the Appeal Court, the French Ministry of Defense reportedly withdrew the decision to donate the boats to Libya. ${ }^{213}$

\section{F. Conclusions: Do EU and UK Due Diligence Policies Stand up to Scrutiny?}

For both the EU and UK, risk assessment appears to be standard practice for assistance projects. Nevertheless, the assessments tend to serve the more limited purpose of operational risk management or policy guidance. ${ }^{214}$ They are not clearly designed to meet the legal obligation of due diligence applicable to the foreseeable human rights risks of arbitrary detention, torture, inhuman and degrading treatment, or refoulement.

Due diligence obligations are violation-specific and depend on the duty holders' ability to have influence over the human rights situation. As obligations of means, the duty holders are obliged to use all reasonable means at their disposal to prevent or to remedy the reasonably foreseeable human rights violations caused by others. What may be considered adequate steps will depend on a context-specific appreciation of the foreseeable risks and the means at the disposal of duty holders.

A risk assessment is needed to clarify the nature and seriousness of the risks, from where they emanate, and how best those risks can be mitigated. Operational risk management tools are vital to help comply with the legal standard of human rights due diligence. But these assessments are merely preconditions, and do not satisfy the due diligence obligations in themselves.

First, the tools need to be sufficiently robust to adequately identify the risks. This Article demonstrates the weaknesses of the risk assessments employed in the area of migration control. For instance, EU trust fund projects do not appear to have been based on transparent or accessible criteria, and what is less clear is the extent to which policies that underpin the projects are subject to a similar assessment process, despite the seriousness of the human rights risks associated with them. Decisions to establish Common Foreign and Security Policy missions and the mandate of those missions should have been subjected to rigorous human rights scrutiny. While the European Parliament has been engaged in some oversight, as has the Fundamental Rights Agency and the European Ombudsperson, these operate at such a length away from the European Council decision making processes that their impact appears to have been limited.

Part of the problem is the duplicity of the programmatic aims of the cooperation. The real purpose underpinning the cooperation is the goal of making it more difficult, if not impossible, for migrants to reach Europe, whereas the assistance projects suggest much more benign,

\footnotetext{
${ }^{210}$ See Corte d'Ass. di Milano, sentenza no 10/17 (Oct. 10, 2017), referred to in Giuseppe Pascale, Is Italy Internationally Responsible for the Gross Human Rights Violations against Migrants in Libya?, QUESTIONS INT'L L. (Feb. 28, 2019), http://www. qil-qdi.org/.

${ }^{211}$ See ANSA, Italian Court Rules Pushback of Eritreans to Libya Illegal, INFOMigRANTs (Dec. 5, 2019), www.infomigrants. net.

${ }^{212}$ See Amnesty Int'l, French Government Challenged Over Unlawful Boat Donation to Libyan Coast Guard (Apr. 25, 2019).

${ }^{213}$ See France Drops Plan to Send Boats to Libyan Navy, Assoc. Press (Dec. 2, 2019), https://apnews.com/ ef3e8f10fb6b4a1f9c6b47f8291df4f8.

${ }^{214} \mathrm{On}$ the distinctions between operational risk management procedures and those which stem from and seek to comply with the legal obligation of human rights due diligence, see Bonnitcha \& McCorquodale, supra note 42 ; McDonald, supra note 86.
} 
humanitarian law enforcement objectives. It is difficult to carry out a robust risk assessment when there is double-speak about the objectives and a failure to engage realistically on the appropriateness of the objectives behind the objectives. Similarly, while UK Ministers have confirmed that OSJA assessments are standard and undertaken in advance of all relevant programming, the Independent Commission on Aid Impact review of migration-related funding concerning Libya found gaps. The UK Government has also indicated that it relied on EU risk analyses when deciding to contribute funds to EU projects. Given the perfunctory nature of EU processes, this is an inadequate approach to identify or mitigate risks.

There appears to have been no effort to consult local or other stakeholders, particularly the groups likely to be affected by the harm and those assisting them. While the political and security context in Libya may have made open consultations difficult, there also does not appear to have been any attempt to engage meaningfully with stakeholders such as migrants in Libya as part of the assessment of risk and determining effective mitigation strategies. To the contrary, the lack of transparency of OSJA assessments underscores the misguided view that risk assessment and mitigation does not require consultation with stakeholders or a degree of public scrutiny in order to be effective. That claims of preserving international relations have succeeded to justify an absence of public scrutiny in cases involving real risks of torture, arbitrary detention, wanton disregard for life at sea, and refoulement, is highly problematic. At the least, consideration should have been given to what steps could have been taken to better balance the public interest in transparency with these other considerations. ${ }^{215}$ The Foreign Affairs Committee's latest inquiry on "[f]inding a diplomatic route: European responses to irregular migration" has provided a useful avenue for NGOs and policy experts to feed in input, although to date, the UK Government has not shown a willingness to change its practice in light of Committee recommendations. Therefore, the direct utility of these inputs for the purposes of policy change appears limited. Similarly, EU Trust Fund risk analyses provide no indication that affected stakeholders have been consulted as part of the process.

Second, mitigation strategies must be designed to meet the risks. An important consideration is the degree of harm that may be generated if the risk materializes. For instance, international law prohibits both torture and refoulement absolutely, with rights that are recognized as nonderogable. $^{216}$ The absolute nature of the violations underscores the importance of taking all possible steps to prevent the harms from materializing-there is no cost-benefit analysis or balancing exercise of competing priorities to determine what course of conduct should be undertaken - the sole consideration is what steps would be effective to eradicate, or sufficiently reduce to an acceptable level, the risk of the harm materializing. The diligence requirement is to take all reasonable steps so that there is no longer a real risk of the harm materializing.

With respect to the duty holders' means for prevention, this would require an analysis of the duty holders' position vis-à-vis the recipient state and capacity to influence the human rights situation in that state. Normally, the capacity to influence will be greatest when a state is seeking to address a situation in its territory or where it exercises effective control. Duty holders may have additional means for prevention, however. Neither the EU nor UK exercise effective control in Libya, wholly or partially, nor do they have such sway with the array of Libyan actors exercising some form of authority within the country of relevance to the human rights situation of migrants. Nevertheless, they still have important means at their disposal to influence the human rights situation, linked to how they apply their funds and provide personnel, material, or other support.

\footnotetext{
${ }^{215}$ See U.K. Information Commissioner's Office, Decision, Ref FS50733635, g9 19, 22 (Sept. 19, 2018), discussed in Section E.II.2.

${ }^{216}$ See Aksoy v. Turkey, 1996-VI Eur. Ct. H.R. 2260, para. 62; Saadi v. Italy (GC), 2008-11 Eur. Ct. H.R. 207, para. 127; Sir Elihu Lauterpacht \& Daniel Bethlehem, The Scope and Content of the Principle of Non-refoulement: Opinion, in REFugEE Protection in International Law: UNHCR's Global Consultations on International Protection 87, 132 (Erika Feller, et al. eds., 2003).
} 
The obligation to use such means that are at their disposal is the method for them to comply with due diligence obligations.

This does not necessarily require the duty holders to suspend assistance. What the Article demonstrates is their failure to adopt realistic and appropriate mitigation measures, such that suspension appears to be, but is not necessarily, the best option to comply with the "do no harm" principle. Some experts have called for the suspension of support. ${ }^{217}$ Others have made clear that suspension must be factored in as one of several possible options: "[T]here should be a willingness not just to delay, but also to cancel programmes if the risk of human rights violations or other harm is high and cannot be effectively mitigated." ${ }^{218}$ Suspension requires a consideration of the separate risks associated with pulling out, but this part of the risk mitigation analysis appeared to be incomplete.

In their seminal report on the human rights crisis affecting migrants in Libya, which has been substantiated further in their follow-up report, ${ }^{219}$ the Office of the High Commissioner for Human Rights and the UN Support Mission in Libya have recommended states to:

Ensure that due diligence policies and measures are in place to mitigate the risk that support to Libyan individuals or institutions results in violations and abuses of the human rights of migrants. In this regard, the European Union should further evaluate its program of training and support to the Libyan Coast Guard and Navy to ensure that its vetting procedures are stringent and its human rights component is comprehensive, including to ensure the protection of migrants at disembarkation points. The European Union should also establish a follow-up monitoring and support mechanism upon completion of the training to assist the Libyan Coast Guard in protecting the rights of those rescued. ${ }^{220}$

Furthermore, none of the risk analyses or related processes that have been reviewed contain grievance procedures, accessible or otherwise. The lack of transparency gives the impression of an unwillingness to engage with outside stakeholders, let alone to permit them access to a procedure by which to register complaints. All this will do is increase the likelihood of court procedures, however inefficient that route is to address the failings of due diligence policies.

Just as it was necessary to bring Italy's push-backs to the European Court in the Hirsi case ${ }^{221}$ it now appears necessary for that Court to adjudicate cooperation with Libyan Coast Guards. ${ }^{222}$ Both the Hirsi and the pending S.S. and Others cases involve Italy, but the policies of which they concern involve an array of additional actors.

Also, the risk analyses contain no mention of remediation plans or implementation. This is perhaps because there has been no acknowledgement of any responsibility for the harms that have already ensued. That there are several parties that may have engaged in and contributed to wrongdoing provides a convenient fogginess for those contributing funding or other assistance over the precise contours of their responsibility.

There are a range of impact assessment tools that states, international organizations, and others have developed in related fields with some success. These should be adapted and applied to this

\footnotetext{
${ }^{217}$ See Foreign Affairs Comm., Finding a Diplomatic Route: European Responses to Irregular Migration Inquiry, Written Evidence Submitted by Dr Mariagiulia Giuffré (ERM0010) (May 7, 2019) (UK); Foreign Affairs Comm., Finding a Diplomatic Route: European Responses to Irregular Migration Inquiry, Written EVidenCE From ReFugEe Rights Europe (ERM0001) (Apr. 24, 2019) (UK).

${ }^{218}$ ICAI, ICAI Follow-Up of: The UK's Aid Response to Irregular Migration in the Central Mediterranean: A Summary of ICAI's Full Follow-Up Review, at 2 (June 2018).

${ }^{219}$ See OHCHR \& UNSMIL, Desperate and Dangerous: Report on the Human Rights Situation of Migrants and Refugees in Libya, at 58-59 (Dec. 20, 2018), https://www.ohchr.org/Documents/Countries/LY/LibyaMigrationReport.pdf.

${ }^{220}$ OHCHR \& UNSMIL, supra note 30 , at 27.

${ }^{221}$ See Hirsi Jamaa, 2012-II Eur. Ct. H.R. at para. 156.

${ }^{222}$ See S.S. v. Italy, App. No. 21660/18.
} 
context to better assess the risks of cooperation, and to put in place effective and realistic mitigation measures, as needed, up to and including the possibility of curtailing cooperation in order to avoid causing or contributing to serious harm. Ultimately, this will improve the potential of such policies to help mitigate the human rights risks associated with extraterritorial assistance, and ideally help ensure that assistance contributes to the strengthening of human rights protections in recipient countries. Improved human rights due diligence policies may-by ensuring that cooperants are fully apprised of the risks and thereby avoiding situations of willful blindness - also help avoid claims of complicity in human rights violations. 